\title{
MULTIPLIER EFFECT PASAR DAERAH TERHADAP PENGEMBANGAN EKONOMI WILAYAH \\ (Studi Kasus di Lingkup Wilayah Pasar Gempol Kab. Pasuruan Prop. Jawa Timur)
}

\author{
Sri Muljaningsih \\ Fakultas Ekonomi Universitas Brawijaya
}

\begin{abstract}
The existence of market is able to give multiplier effect towards the community economy and the economic development of the region. Supported by infrastructure, as transport facilities like road and travel mode, moreover strategic location in a sense of the existence of this market, has high accessibility. This is identified by the road networks that connected intercity/the territory with the location of this market. Appropriately the function of the market is linked with trade and the other field related like the agriculture and non agriculture industries. However to determine the policy strategy of market function development, not only based on economic based models (LQ $\&$ Shift-Share), there are inputs of multiplier effect analysis, but must also be supported by the SWOT analysis that give consideration of the strength, the weakness, opportunity and the threat that is influenced by the internal and external factor. Majority of the people at Pasuruan Municipal in agricultural sector, so agribusiness can accelerated community economic growth as well as the region growth However the agribusiness sector need market in the strategic location and supported by infrastructure.
\end{abstract}

Keywords: market, economic based, multiplier effect, transportation, agribusiness

\section{A. LATAR BELAKANG}

Penyediaan sarana pasar daerah secara langsung dapat memberikan dampak secara signifikan terhadap perkembangan suatu wilayah. Secara spasial dapat dijelaskan bahwa pasar secara langsung akan menjadi pusat pelayanan baru yang dapat memicu munculnya kegiatan lanjutan lainnya. Sedangkan berdasarkan aspek transportasi diketahui bahwa pasar menjadi salah satu faktor penarik dan pembangkit arus lalu-lintas yang membebani jaringan jalan di sekitarnya sehingga semakin besar skala pasar tersebut maka semakin besar pula bangkitan dan tarikan lalu-lintas yang ditimbulkan. Mengingat fungsi pasar sebagai pusat pelayanan kegiatan ekonomi masyarakat di dalam suatu wilayah. Selain itu mempunyai keterkaitan dengan sektor perdagangan terhadap barang dan jasa. Dengan demikian perlu mengetahui potensi ekonomi yang mendasar (economic based). Setelah diketahui basis ekonominya perlu mengetahui apakah memberikan multiplier effect yang berarti (significant) bagi pengembangan ekonomi wilayah.

Untuk mengetahui hal tersebut, maka diadakan penelitian dengan mengambil studi kasus peranan pasar di Kecamatan Gempol Kabupaten Pasuruan terhadap pengembangan ekonomi bagi wilayah sekitarnya. Telah diketahui secara umum potensi yang dimiliki oleh Kecamatan Gempol dan wilayah sekitarnya, seperti: kerajinan kulit (tas dan ikat pinggang), industri konveksi, dan potensi lainnya serta kerajinan bordir di wilayah Kecamatan Bangil dan secara umum masyarakatnya bergerak di bidang pertanian.

Sementara itu, untuk kebutuhan bahan baku dari kegiatan usaha tersebut saat ini masih diperoleh 
dari pasar yang berada di luar wilayah Kabupaten Pasuruan. Lokasi pasar sangat menentukan jangkauan pelayanan yang tidak terlepas dari sistem jaringan jalan. Oleh karena itu peranan pasar terhadap pengembangan ekonomi wilayah akan dipengaruhi perencanaan transportasi. Kondisi transportasi saat ini di jalur jalan arah pasar Gempol yang berbatasan dengan Kecamatan Porong yang dilanda bencana lumpur Sidoarjo, sering mengalami kemacetan pada jam-jam tertentu. Hal ini apakah memberikan keuntungan atau kerugian bagi pasar Gempol dan bagaimana kemungkinan pembangunan jalan toll baru yang masih dalam taraf perencanaan. Keadaan tersebut merupakan permasalahan yang perlu diantisipasi, maka perlu diadakan penelitian yang mengkaji keberadaan pasar Gempol saat ini terhadap pengembangan ekonomi wilayah sekitarnya.

\section{Tujuan Penelitian}

Tujuan penelitian ini berdasarkan rumusan masalah yaitu:

1. Identifikasi potensi basis ekonomi di Kabupaten Pasuruan

2. Mengetahui potensi basis ekonomi yang terkait dengan pasar Gempol

3. Mengetahui multiplier efect terhadap pengembangan ekonomi wilayah sekitar pasar Gempol.

\section{Lingkup Penelitian}

Ruang lingkup dari tulisan ini adalah untuk mengetahui keberadaan pasar Gempol, apakah memberikan multiplier effect terhadap ekonomi masyarakat di wilayah sekitarnya, yang meliputi Kecamatan Gempol, Bangil, Beji dan Pandaan yang berada di wilayah Kabupaten Pasuruan Propinsi Jawa Timur. Untuk menyederhanakan ruang lingkup tersebut di tunjukkan pada gambar.1. berupa bagan alir sebagai berikut :

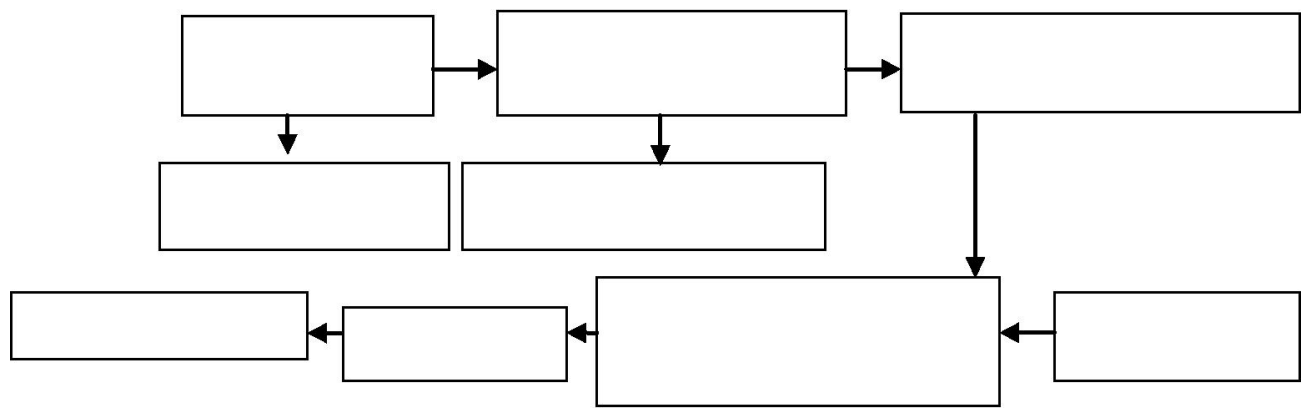

\section{Gambar 1. Lingkup Penelitian}

\section{METODE PENELITIAN DAN ANALISIS DATA}

\section{Metode Pengumpulan Data}

Untuk pengumpulan data dilakukan melalui survei terhadap data primer dan data sekunder, yang diuraikan sebagai berikut:

a. Survei Primer

Survei primer yang dilakukan pada penelitian adalah dokumentasi terhadap kondisi riil Pasar Daerah Gempol. Dokumentasi ini meliputi kondisi fisik Pasar Daerah Gempol, kondisi jalan arus lalu-lintas di sekitar Pasar Daerah Gempol, karakteristik pengguna pasar meliputi pedagang, paguyuban pedagang, dan pembeli, serta tanggapan masyarakat di sekitar Pasar Daerah Gempol terkait dengan pengembangan fungsi pasar.

b. Survei Sekunder

Metode pengumpulan data dengan survey sekunder dalam kegiatan ini menggunakan alat berupa dokumentasi. Dokumentasi adalah pengumpulan data yang menyelidiki benda-benda tertulis seperti buku-buku, majalah, dokumen, peraturan-peraturan, notulen rapat, catatan harian dan sebagainya. 


\section{Metode Analisis}

Metode analisis yang digunakan pada penelitian ini adalah metode analisis deskriptif dan metode analisis evaluatif yang akan diuraikan sebagai berikut:

\section{Analisis Deskriptif}

Analisis deskriptif merupakan suatu metode analisis yang memaparkan, menjelaskan suatu data/ fakta dengan menggunakan tabel, diagram, gambar maupun peta dengan tujuan agar lebih mudah untuk dibaca dan dipahami.

\section{Analisis Evaluatif}

Analisis evaluatif merupakan metode analisis yang berfungsi untuk menilai sesuatu berdasarkan standar baku. Analisis evaluatif yang dilakukan pada penyusunan perencanaan pengembangan ekonomi masyarakat di Kabupaten Pasuruan melalui perencanaan pengembangan Pasar Daerah Gempol diuraikan sebagai berikut.

\section{Analisis Basis Ekonomi}

a. Analisis LQ

Analisis LQ (Location Quotions) merupakan metode analisis yang dapat digunakan untuk mengukur konsentrasi dari suatu kegiatan dalam suatu daerah dengan cara membandingkan peranan perekonomian daerah tersebut dengan peranan kegiatan sejenis dalam perekonomian regional atau nasional. Secara umum metode analisa LQ dapat diformulasikan sebagai berikut:

$$
L Q=\frac{\text { Sektor }_{i j} / P D R B_{j}}{\text { Sektor }_{i k} / P D R B_{k}}
$$

Dengan:

Sektor $\mathrm{ij} \quad=$ sektor $\mathrm{i}$ pada daerah $\mathrm{j}$

PDRB $\mathrm{j}=$ PDRB pada daerah $\mathrm{j}$

Sektor ik = sektor i pada daerah $\mathrm{k}$ yang lebih luas dari daerah $\mathrm{j}$

PDRB $\mathrm{k}=$ PDRB pada daerah yang lebih luas dari $\mathrm{j}$

Ukuran/besaran yang dapat dipakai antara lain tenaga kerja dan hasil produksi dari sektor kegiatan. Metode ini berguna untuk menunjukkan dominasi dan peranan suatu sektor kegiatan dalam lingkup Kabupaten Pasuruan.

Berdasarkan hasil perhitungan LQ, dapat diketahui konsentrasi suatu kegiatan pada suatu wilayah dengan kriteria sebagai berikut:

o Jika nilai $\mathrm{LQ}<1$, maka sektor yang bersangkutan kurang terspesialisasi dibanding sektor yang sama di tingkat daerah tertentu, sehingga bukan merupakan sektor unggulan.

o Jika nilai $\mathrm{LQ}=1$, sektor yang bersangkutan memiliki tingkat spesialisasi yang sama dengan sektor sejenis di tingkat daerah tertentu, sehingga hanya untuk melayani kebutuhan sendiri.

o Jika nilai $L Q>1$, sektor yang bersangkutan lebih terspesialisasi dibanding sektor yang sama di tingkat daerah tertentu, sehingga merupakan sektor unggulan.

b. Analisis Share

Analisis share atau pangsa adalah menggambarkan kontribusi(sumbangan) masingmasing sektor terhadap total sektor, dengan sebagai berikut:

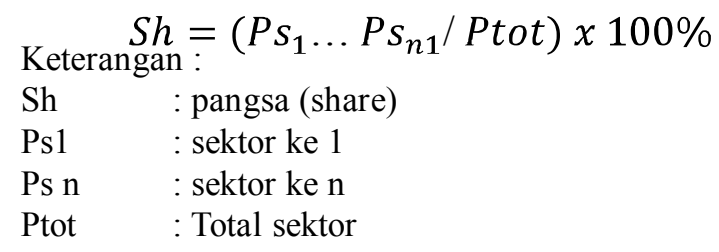




\section{Analisis SWOT}

Analisis SWOT merupakan salah satu teknik analisis yang digunakan dalam menginterpretasikan wilayah perencanaan, khususnya pada kondisi yang sangat kompleks dimana faktor eksternal dan internal memegang peran yang sama pentingnya. Analisis SWOT digunakan untuk penelaahan terhadap kondisi fisik, ekonomi dan sosial serta kelembagaan. Berdasarkan penelaahan terhadap wilayah maka dihasilkan potensi dan masalah pengembangan tersebut yang digunakan untuk menentukan arah pengembangan. Analisis ini digunakan untuk mengetahui inventarisasi faktorfaktor:

o Potensi (Strenght)

Kekuatan apa yang dapat di kembangkan agar lebih tangguh sehingga dapat bertahan di pasaran, yang berasal dari dalam wilayah itu sendiri.

o Masalah (Weakness)

Segala faktor yang merupakan masalah atau kendala yang datang dari dalam wilayah atau obyek itu sendiri.

o Peluang (Opportunities)

Kesempatan yang berasal dari luar wilayah atau obyek studi, kesempatan tersebut di berikan sebagai akibat dari pemerintah, peraturan-peraturan atau kondisi perekonomian secara global.

o Ancaman (Threats)

Merupakan hal yang dapat mendatangkan kerugian yang berasal dari luar wilayah atau obyek. Kekuatan dan kelemahan merupakan faktor intern, sedangkan kesempatan dan ancaman merupakan faktor ekstern.

Matriks analisis SWOT dengan menjabarkan dan mengkombinasikan masing-masing variabel. Matriks analisis SWOT dibuat dengan mengaitkan 2 poin yang saling berkaitan dan berhubungan sebagai berikut:

SO : Memanfaatkan kekuatan (S) secara maksimal untuk dapat meraih peluang $(\mathrm{O})$ yang tersedia.

ST : Memanfaatkan kekuatan (S) secara maksimal untuk mengantisipasi atau menghadapi ancaman ( $\mathrm{T}$ ) dan berusaha maksimal menjadikan ancaman sebagai peluang.

WO : Meminimalkan kelemahan (W) untuk meraih peluang $(\mathrm{O})$

WT : Meminimalkan kelemahan (W) untuk menghindari secara lebih baik dari ancaman (T).

Tabel 1. Matriks Analisis SWOT

\begin{tabular}{|c|c|c|}
\hline $\begin{array}{l}\text { External } \\
\text { Environ m en } t\end{array}$ & $\begin{array}{c}\text { Strenght } \\
\text { (S) } \\
\text { Kekuatan }\end{array}$ & $\begin{array}{l}\text { W e a k ness } \\
(\text { W ) } \\
\text { Kelem ah an }\end{array}$ \\
\hline $\begin{array}{l}\text { Opportunity (O) } \\
\text { Kes empatan }\end{array}$ & SO & W O \\
\hline $\begin{array}{l}\text { Threat }(\mathrm{T}) \\
\text { Ancam an }\end{array}$ & S T & W T \\
\hline
\end{tabular}

Sumber: Yoeti, 1996:143

\section{HASIL DAN PEMBAHASAN}

\section{Kebijakan Terkait Dengan Pasar di Kabupaten Pasuruan}

Pasar adalah tempat terjadinya peristiwa transaksi atau pertukaran antara penjual dan pembeli baik secara langsung maupun tidak langsung (menggunakan saluran komunikasi lain). Pengertian mengenai pasar dapat dilihat dari beberapa konteks , diantaranya adalah:

1. Konsep pasar 


\section{Journal of Indonesian Applied Economics \\ Vol. 3 No. 2 Oktober 2009, 178-199}

Pasar terdiri dari semua pelanggan potensial yang memiliki kebutuhan atau keinginan tertentu mau dan mampu turut dalam pertukaran untuk memenuhi kebutuhan atau keinginan itu.

2. Istilah pasar

Istilah pasar dapat dibagi dalam beberapa sudut pandang:

- Lokasi(tempat) : pasar menunjukkan tempat di mana penjual dan pembeli berkumpul untuk bertukar barang-barang mereka, misalnya di alun-alun dan tempat lainnya.

- Ahli ekonomi : pasar untuk menunjuk pada sejumlah pembeli dan penjual yang melakukan transasksi pada suatu produk atau kelas produk, amak muncul istilah pasar perumahan, pasar beras, pasar gandum dan seterusnya.

- Kalangan bisnis : pasar untuk mencakup berbagai pengelompokan pelanggan. Ada pasar keinginan(misalnya pasar pencari diet), pasar produk(seperti pasar sepatu), pasar demografis(seperti pasar remaja), pasar geografis(seperti pasar Jawa Timur). Bahkan istilah ini mencakup kelompok bukan pelanggan seperti pasar pemilih, pasar pencari kerja dan pasar penyumbang, serta pasar produk pertanian(agri bissnis).

- Ekonomi modern : pasar ,atas dasar pembagian pekerjaan di mana setiap orang mengkhususkan diri memproduksi sesuatu, menerima bayaran dan membeli barang yang dia butuhkan dengan uang tersebut. Jadi ada banyak pasar dalam ekonomi modern. Seperti pasar bahan baku, pasar kerja, pasar uang dan seterusnya.

\section{Pemasaran}

Pemasaran adalah kegiatan manusia dalam hubungannya dengan pasar. Pemasaran maksudnya bekerja dengan pasar untuk mewujudkan transaksi yang mungkin terjadi dalam memenuhi kebutuhan dan keinginan manusia. Konsep tersebut didefinisikan, pemasaran adalah proses social dan manajerial di mana individu dan kelompok mendapatkan kebutuhan dan keinginan mereka dengan menciptakan, menawrkan dan menukarkan produk yang bernilai satu sama lain.

4. Pemasar

Pemasar adalah orang yang mencari sumberdaya dari orang lain dan mau menawarkan sesuatu yang bernilai untuk itu. Si pemasar mencari suatu tanggapan dari pihak lainnya, baik menjual atau memberi sesuatu. Dalam situasi normal, pemasar adalah suatu perusahaan yang melayani suatu pasar pemakai di tengah kompetisi. Perusahaan dan sainngannya mengirimkan masingmasing produk dan pesannya baik secara langsung atau melalui perantara pemasaran(perantara dan fasilitator) kepada pemakai akhir. Kefektifan mereka dipengaruhi oleh masing-masing pemasok mereka dan juga factor utama lingkungan (demografi,ekonomi,fiscal,teknologi,politik,hukum,social buadaya).

Berdasarkan Keputusan Bupati Dati II Pasuruan Nomor 367 Tahun 1995, bahwa pasar yang terdapat di Kabupaten Pasuruan dapat dibagi menjadi 3 kelas, yaitu:

A. Pasar Daerah Kelas I: Pasar Daerah Pandaan, Bangil, Wonorejo,Pasrepan, Sukorejo, Purwosari.

B. Pasar Daerah Kelas II: Pasar Daerah Gondangwetan, Gempol, Warungdowo, Nguling.

C. Pasar Daerah Kelas III: Pasar Winongan, Prigen, Ngempit, Grati dan Gondang Legi.

Selanjutnya untuk sumber penerimaan daerah yang berasal dari retribusi pasar di Kabupaten Pasuruan penggaliannya didasarkan pada Peraturan Daerah Kabupaten Pasuruan Nomor 1 Tahun 2004 tentang Retribusi Pasar. strasi Kecamatan Gempol 


\section{Gambaran Umum Wilayah Kajian}

Gambaran umum wilayah kajian ini meliputi wilayah administrasi , kependudukan , kondisi ekonomi makro, potensi sektor pertanian dan potensi sektor industri yang akan diuraikan sebagai berikut:

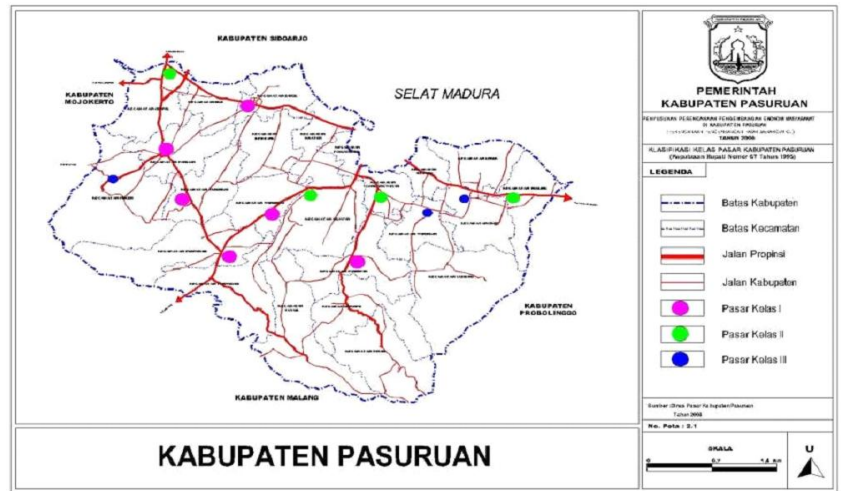

Gambar 2. Wilayah Administrasi Kabupaten Pasuruan

\section{Wilayah Administrasi}

Secara administrasi, wilayah yang akan dikaji terkait dengan rencana pengembangan Pasar Daerah Gempol terdiri dari Kecamatan Bangil, Kecamatan Beji, Kecamatan Gempol, serta Kecamatan Pandaan. Kecamatan Bangil memiliki luas wilayah 4.460 Ha yang terdiri atas 4 desa/ kelurahan. Kecamatan Beji terdiri atas 12 desa/kelurahan dengan luas wilayah $3.990 \mathrm{Ha}$.

Kecamatan Gempol terdiri atas 15 desa/kelurahan dengan luas wilayah 6.492 Ha. Kecamatan Pandaan terdiri atas 14 desa/kelurahan dengan luas wilayah 4.327 Ha. Adapun batasan wilayah kajian adalah (Gambar 3.3):

" Sebelah Utara : Kabupaten Sidoarjo

" Sebelah Timur : Kecamatan Kraton

" Sebelah Selatan : Kecamatan Prigen, Rembang, dan Sukorejo

" Sebelah Barat : Kabupaten Mojokerto

\section{Kependudukan}

Perkembangan jumlah penduduk wilayah kajian dari tahun ke tahun tidak mengalami peningkatan yang cukup signifikan dan cenderung linier. Dalam kurun waktu 2005-2007 tingkat pertumbuhan tertinggi terjadi pada tahun 2006-2007 sebesar 1,12\%. Berdasar jumlah penduduk, Kecamatan Gempol merupakan kecamatan dengan jumlah penduduk terbanyak di wilayah kajian yaitu tercatat sebesar 116.239 jiwa pada tahun 2007, sementara itu jumlah penduduk terendah pada Kecamatan Beji yaitu sebesar 77.375 jiwa pada tahun 2007.

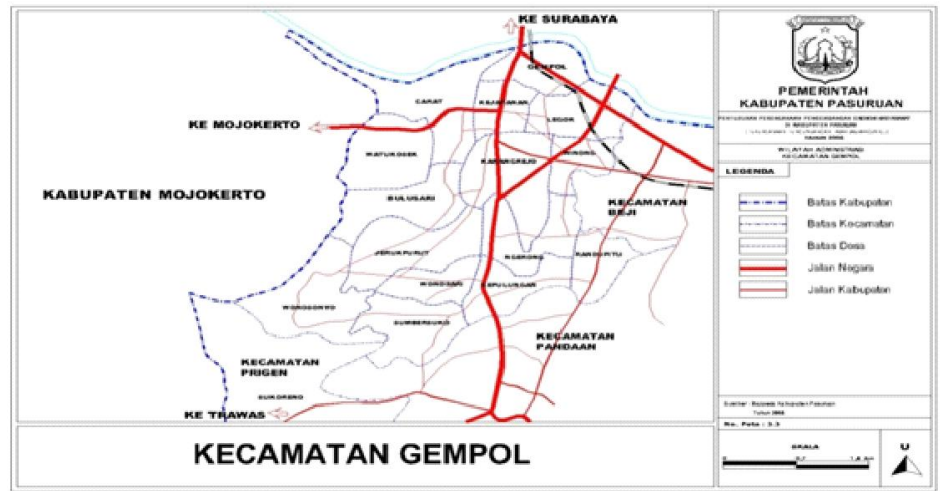

Gambar 2. Kecamatan Gempol 


\section{Journal of Indonesian Applied Economics}

Vol. 3 No. 2 Oktober 2009, 178-199

Struktur penduduk wilayah kajian menurut mata pencaharian menunjukkan bahwa sebagian besar penduduk bekerja disektor pertanian (29\%) dari total penduduk yang bekerja). Hal ini mengindikasikan bahwa sektor pertanian memberikan pengaruh yang cukup dominan pada lapangan pekerjaan di wilayah kajian terutama pada Kecamatan Gempol. Kondisi tersebut merupakan suatu potensi dalam mendukung pengembangan Pasar Daerah Gempol dimana sektor pertanian merupakan salah satu sektor penggerak ekonomi masyarakat dan berkorelasi cukup erat dengan sektor perdagangan, sehingga keberadaan Pasar Daerah Gempol dapat berfungsi menjadi sarana promosi atau lokasi transaksi komoditas pertanian yang dihasilkan di wilayah kajian terutama untuk produk/ komoditas pertanian unggulan Kabupaten Pasuruan. Selanjutnya informasi tentang struktur penduduk berdasarkan mata pencaharian di wilayah kajian dapat dilihat pada Tabel 1. berikut ini.

Tabel 1. Struktur Penduduk Berdasar Jenis Mata Pencaharian Wilayah Kajian Tahun 2007

\begin{tabular}{|c|c|c|c|c|c|c|}
\hline \multirow{2}{*}{$\begin{array}{c}\text { Jenis } \\
\text { Pekerjaan }\end{array}$} & \multicolumn{4}{|c|}{ Kecamatan (jiwa) } & \multirow{2}{*}{$\begin{array}{c}\text { Jumlah } \\
\text { (jiwa) }\end{array}$} & \multirow[t]{2}{*}{$(\%)$} \\
\hline & Bangil & Beji & Gempol & Pan daan & & \\
\hline Petani & 14.511 & 9.712 & 39.455 & 3.096 & 66.774 & 28,63 \\
\hline PNS & 1.750 & 736 & 1.515 & 1.515 & 5.516 & 2,37 \\
\hline TNI/POLRI & 2.710 & 155 & 543 & 355 & 3.763 & 1,61 \\
\hline Pedagang & 10.170 & 1.958 & 2.056 & 12.714 & 26.898 & 11,53 \\
\hline $\begin{array}{l}\text { Pegawai } \\
\text { Swasta }\end{array}$ & 10.710 & 8.154 & 15.192 & 19.479 & 53.535 & 22,96 \\
\hline Ja sa & 6.150 & 13.509 & 1.337 & 1.947 & 22.943 & 9,84 \\
\hline Lainnya & 2.775 & 39.113 & 10.679 & 1.196 & 53.763 & 23,06 \\
\hline Jumlah/Total & 48.776 & $\mathbf{7 3 . 3 3 7}$ & 70.777 & 40.302 & 233.192 & 100,00 \\
\hline
\end{tabular}

Sumber: Kabupaten Pasuruan Dalam Angka Tahun 2008

\section{Kondisi Ekonomi Makro Wilayah Kajian}

Pada wilayah kajian kecamatan dengan PDRB terbesar adalah Kecamatan Gempol, hal tersebut mengindikasikan bahwa potensi perekonomian Kecamatan Gempol cukup besar untuk dikembangkan. Berdasarkan PDRB Kecamatan, sektor ekonomi yang memiliki kontribusi yang cukup besar dalam mendukung pertumbuhan ekonomi dan perkembangan masing-masing wilayah adalah sektor industri pengolahan dan sektor perdagangan, hotel, dan restoran. Kecamatan dengan nilai sektor industri pengolahan tertinggi adalah Kecamatan Beji. Sementara itu kecamatan dengan nilai sektor perdagangan, hotel, dan restoran

tertinggi adalah Kecamatan Pandaan. Pada Kecamatan Gempol, sektor utama yang berperan dalam mendukung pertumbuhan dan perkembangan ekonomi wilayah adalah sektor industri pengolahan. Dominasi sektor-sektor sekunder tersebut diharapkan dapat mendukung terhadap perkembangan sektor primer. Selanjutnya nilai tiap sektor ekonomi yang membentuk PDRB Kecamatan pada wilayah kajian pada Tahun 2006 dapat dilihat pada Tabel 2. berikut ini.

Tabel 2. PDRB Kecamatan pada Wilayah Kajian Atas Dasar Harga Konstan Tahun 2006

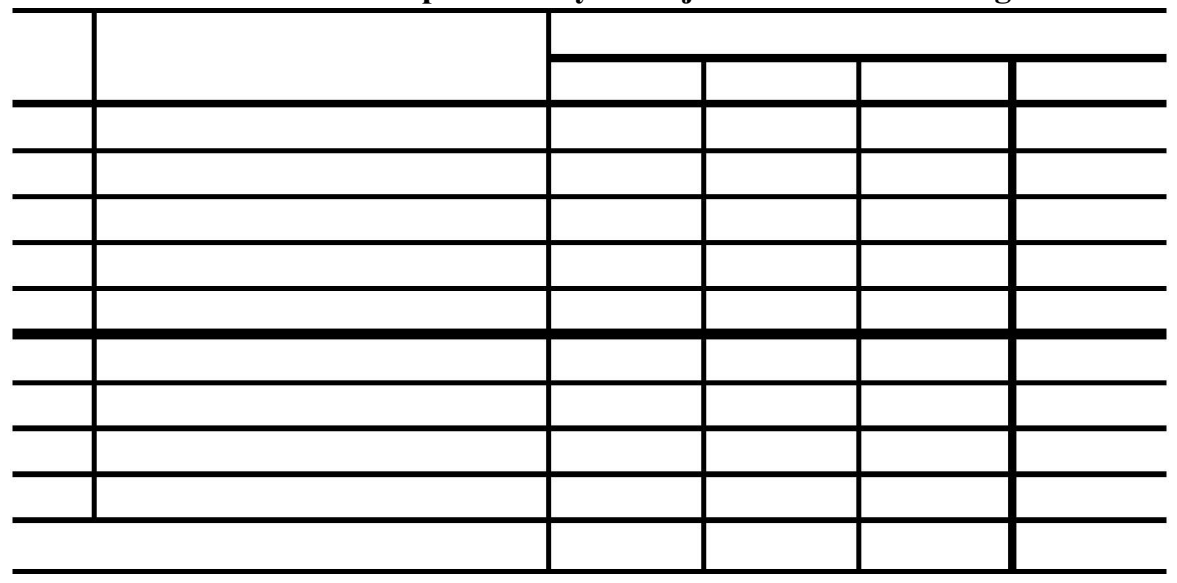

Sumber : BPS Kab. Pasuruan Tahun 2008 


\section{Potensi Sektor Pertanian Wilayah Kajian}

Sektor pertanian merupakan salah satu sektor yang memiliki keterkaitan erat dengan sektor perdagangan, Hal ini diindikasikan oleh diperjualbelikannya produk-produk pertanian merupakan komoditi yang diperjual-belikan pada fasilitas-fasilitas perdagangan. Kondisi tersebut terutama pada wilayah yang perekonomiannya bertumpu pada sektor primer. Kabupaten Pasuruan juga merupakan salah satu wilayah yang perkembangan wilayahnya masih bertumpu pada sektor pertanian. Perkembangan sektor pertanian pada Kabupaten Pasuruan paling tidak akan mempengaruhi perkembangan wilayah Kabupaten Pasuruan. Pada wilayah kajian, sektor pertanian masih memegang peranan cukup penting dalam perkembangan dan pertumbuhan wilayahnya meskipun tidak dominan. Informasi mengenai produk pertanian yang dihasilkan pada wilayah kajian secara rinci dapat dilihat pada Tabel 3. berikut ini.

Tabel 3. Jenis dan Jumlah Produk Pertanian yang Dihasilkan pada Wilayah Kajian

\begin{tabular}{|c|c|c|c|c|c|}
\hline \multirow[t]{2}{*}{ No. } & \multirow[t]{2}{*}{ Produk } & \multicolumn{4}{|c|}{ Kecam ata $n$} \\
\hline & & $\frac{\text { B a n gil }}{1461324}$ & $\begin{array}{c}\text { B ej i } \\
\end{array}$ & $\begin{array}{l}\text { G e m p o l } \\
2637866\end{array}$ & $\begin{array}{l}P \text { a nd a a n } \\
38,38930\end{array}$ \\
\hline 2 . & Jagung & 64,19 & - & $2.118,00$ & - \\
\hline 3. & Ub i K a yu & 746,88 & - & $1.344,69$ & - \\
\hline 4. & $\begin{array}{l}\text { Kacang } \\
\text { T an ah }\end{array}$ & - & 111,80 & 244,17 & - \\
\hline $\begin{array}{l}5 . \\
6 .\end{array}$ & $\begin{array}{l}\text { Kedelai } \\
\text { Kacang Hijau }\end{array}$ & 275,56 & $\begin{array}{r}1.486,70 \\
4,90\end{array}$ & $\begin{array}{l}338,52 \\
189,28\end{array}$ & $\begin{array}{r}2.153,77 \\
79,77\end{array}$ \\
\hline 7. & Ke la pa & 35,00 & 42,00 & 103,00 & 42,00 \\
\hline 8 . & $\mathrm{Kapuk}$ R and u & 11,00 & 90,00 & 142,00 & 85,00 \\
\hline 9 . & Jam bu M ete & 7,00 & 26,00 & 114,00 & 7,00 \\
\hline 10. & $\mathrm{Ke} n$ an $\mathrm{g}$ a & - & 35,00 & 4,00 & 40,00 \\
\hline 11. & $\mathrm{Tebu}$ & - & 357,03 & $1.642,67$ & 148,68 \\
\hline 12. & Jah e & - & - & 117,00 & 110,00 \\
\hline 13. & $\mathrm{Kuny}$ it & - & - & 100,00 & 126,00 \\
\hline 14. & T em u la wak & - & - & 56,50 & 63,00 \\
\hline
\end{tabular}

Sumber : Survey Primer Tahun 2008

\section{Potensi Sektor Industri Wilayah Kajian}

Diantara beberapa sektor yang terdapat di Kabupaten Pasuruan, sektor industri merupakan salah satu sektor yang potensial untuk dikembangkan dalam mendukung pengembangan ekonomi masyarakat, terutama sektor industri kecil. Sektor industri kecil Kabupaten Pasuruan saat ini telah berkembang dan menghasilkan berbagai macam produk atau komoditi yang berpotensi mampu menjadi produk unggulan Kabupaten Pasuruan, seperti: makanan, konveksi, meubel, bordir, sandal dan sepatu, dan kerajinan perhiasan perak. Produk atau komoditi unggulan tersebut terutama dihasilkan oleh aktivitas industri kecil di wilayah kajian. Seiring dengan perkembangan industri kecil tersebut, juga terdapat beberapa hal yang mampu menghambat perkembangan seperti minimnya sarana promosi dan transakasi sehingga kemampuan pemasaran sangat terbatas serta bahan baku industri yang masih harus dibeli atau didatangkan dari luar Kabupaten Pasuruan sehingga memperbesar biaya produksi. Informasi mengenai jenis dan jumlah industri pada tiap kecamatan di wilayah kajian dapat dilihat pada tabel 4. dibawah ini. 
Tabel 4. Jumlah dan Jenis Industri Kecil yang terdapat di Wilayah Kajian

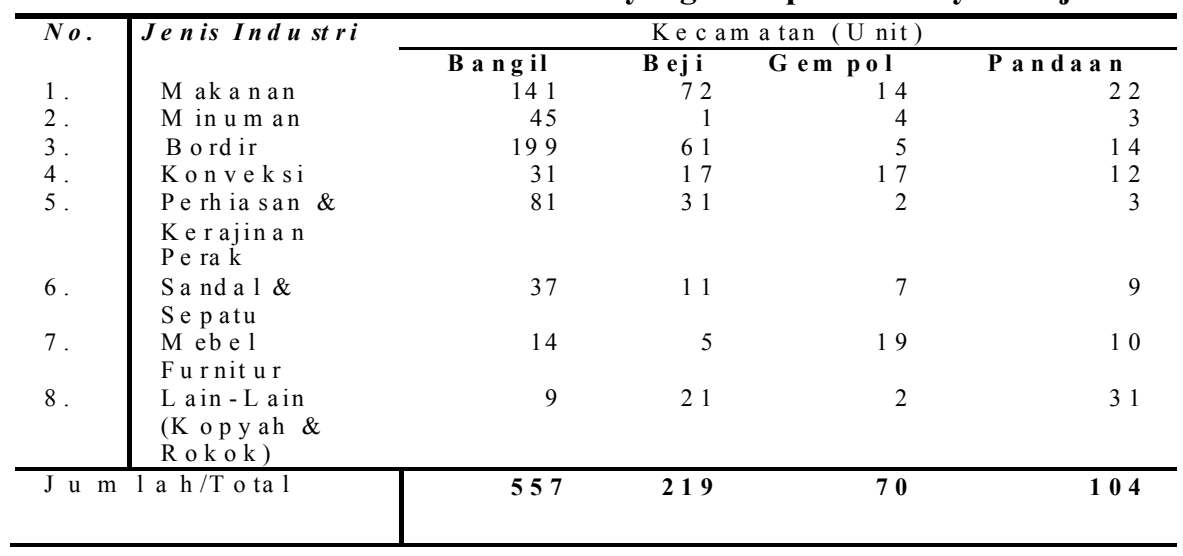

Sumber : Survey Primer Tahun 2008

Berdasar pengamatan di lapangan, diketahui banyak terdapat aktivitas industri kecil ataupun home industri pada wilayah kajian. Jumlah aktivitas industri kecil paling banyak terdapat di Kecamatan Bangil sementara itu aktivitas industri paling sedikit terdapat di Kecamatan Gempol karena pada kecamatan ini lebih dominan aktivitas industri berskala menengah dan besar. Industri kecil di wilayah kajian sendiri menghasilkan beberapa produk, seperti: makanan (tempe, krupuk, jenang, serta makanan), kerajinan bordir, konveksi (busana muslim), kerajinan perak (perhiasan), sandal dan sepatu, meubel furniture, serta produk lain (kopyah dan rokok). Berdasar pada kondisi tersebut, beberapa industri kecil dinilai cukup berpotensi untuk menjadi produk unggulan Kabupaten Pasuruan karena jumlah aktivitas industri terkait adalah disamping jumlahnya cukup banyak juga produk yang dihasilkan dinilai memiliki keunikan lokal sehingga mampu merepresentasikan bahwa produk tersebut memang berasal dari Kabupaten Pasuruan dan bukan dari daerah lain. Produk atau komoditi tersebut berupa bordir dan kerajinan perak.

\section{Analisis Basis Ekonomi}

Fokus dari analisa basis ekonomi untuk mengetahui sektor-sektor ekonomi potensial pada tiap kecamatan di Kabupaten Pasuruan. Tinjauan terhadap sektor-sektor ekonomi pada tiap kecamatan di Kabupaten Pasuruan tersebut diperlukan untuk mendukung rencana pengembangan ekonomi masyarakat di Kabupaten Pasuruan melalui rencana pengembangan Pasar Daerah Gempol.

a. Analisis Location Qoution (LQ)

Analisa LQ digunakan untuk mengukur kemampuan suatu wilayah dalam sektor ekonomi tertentu. Sektor ekonomi dengan nilai LQ lebih dari 1 mengindikasikan bahwa sektor ekonomi pada wilayah tersebut berpotensi untuk berkembang serta mampu mendukung pertumbuhan ekonomi dan perkembangan wilayah secara keseluruhan. Perhitungan analisa LQ ini didasarkan pada data PDRB tiap kecamatan di Kabupaten Pasuruan atas dasar harga konstan pada tahun 2006. Sektorsektor ekonomi yang akan dikaji dalam analisa LQ ini adalah sektor-sektor ekonomi yang diperkirakan mempengaruhi rencana pengembangan Pasar Daerah Gempol yaitu sektor pertanian, industri pengolahan, dan perdagangan.

Berdasarkan hasil perhitungan analisa LQ dapat diketahui bahwa pada sektor pertanian, terdapat 14 kecamatan dengan nilai LQ $>1$. Nilai LQ tertinggi pada Kecamatan Puspo dan Kecamatan Lumbang, dengan nilai masing-masing sebesar 2,25 dan sebesar 2,23. Nilai ini menunjukkan bahwa kecamatan tersebut memiliki produktivitas pertanian yang tinggi yang berpotensi menjadi sektor unggulan. Banyaknya kecamatan dengan nilai LQ yang tinggi mengindikasikan bahwa sektor pertanian masih menjadi sektor potensial di Kabupaten Pasuruan. Sedangkan nilai LQ terendah secara berturut-turut terdapat pada Kecamatan Gempol sebesar 0.33, Kecamatan Beji sebesar 0.34, Kecamatan Pandaan sebesar 0.43, dan Kecamatan Bangil sebesar 0,48. Hasil tersebut menunjukkan bahwa sektor pertanian di wilayah kajian (Kecamatan Gempol, Kecamatan Bangil, Kecamatan 
Beji, dan Kecamatan Pandaan) kurang berkembang.

Pada sektor industri pengolahan, terdapat 7 kecamatan dengan nilai LQ $>1$. Ketujuh kecamatan dengan nilai LQ potensial tersebut memiliki kawasan industri atau sentra industri pengolahan pada wilayah administrasinya. Kecamatan Beji memiliki nilai LQ tertinggi daripada kecamatan lain di Kabupaten Pasuruan. Kemudian pada wilayah kajian hanya Kecamatan Gempol dan Kecamatan Pandaan juga memiliki nilai LQ $>1$. Banyaknya kecamatan (terutama pada wilayah kajian) dengan nilai LQ sektor industri pengolahan yang positif menunjukkan bahwa sektor industri pengolahan merupakan sektor ekonomi potensial yang mampu mendukung pertumbuhan ekonomi dan perkembangan wilayah Kabupaten Pasuruan. Hal tersebut dibuktikan oleh banyaknya kawasan industri skala besar serta sentra-sentra industri kecil dan menengah yang keberadaannya tersebar pada hampir seluruh wilayah Kabupaten Pasuruan.

Untuk sektor perdagangan, diketahui terdapat 7 kecamatan dengan nilai LQ $>1$, termasuk Kecamatan Gempol. Kecamatan dengan nilai LQ pada sektor perdagangan yang cukup tinggi adalah Kecamatan Prigen, Kecamatan Tosari, dan Kecamatan Bangil. Pada Kecamatan Prigen dan Kecamatan Tosari, nilai LQ yang tinggi tersebut lebih disebabkan keberadaan obyek wisata yang mampu meningkatkan perkembangan sektor perdagangan terutama untuk sub sektor hotel dan restoran. Sementara itu, nilai LQ sektor perdagangan pada Kecamatan Bangil yang tinggi disebabkan Kecamatan Bangil merupakan pusat pertumbuhan Kabupaten Pasuruan yang memiliki fungsi perdagangan berskala regional. Sedangkan nilai LQ terendah pada sektor perdagangan terdapat pada Kecamatan Rembang. Pada wilayah kajian, Kecamatan Gempol dan Kecamatan Pandaan juga memiliki nilai $L Q>1$ sehingga sektor perdagangan pada wilayah kajian berpotansi untuk berkembang.

Sementara pada sektor jasa diketahui terdapat 10 kecamatan dengan nilai LQ>1. Nilai LQ tertinggi pada sektor jasa terdapat pada Kecamatan Winongan, sedangkan nilai LQ terendah terdapat pada Kecamatan Tosari. Pada wilayah kajian, hanya Kecamatan Gempol dan Kecamatan Bangil yang memiliki nilai LQ>1 sehingga hanya pada kedua kecamatan tersebut sektor jasa berpotensi untuk berkembang. Hasil perhitungan LQ Kabupaten Pasuruan dapat dilihat pada Tabel 5

Tabel 5. Analisa LQ Sektor Pertanian, Industri Pengolahan, Perdagangan, dan Jasa tiap Kecamatan di Kabupaten Pasuruan Tahun 2006

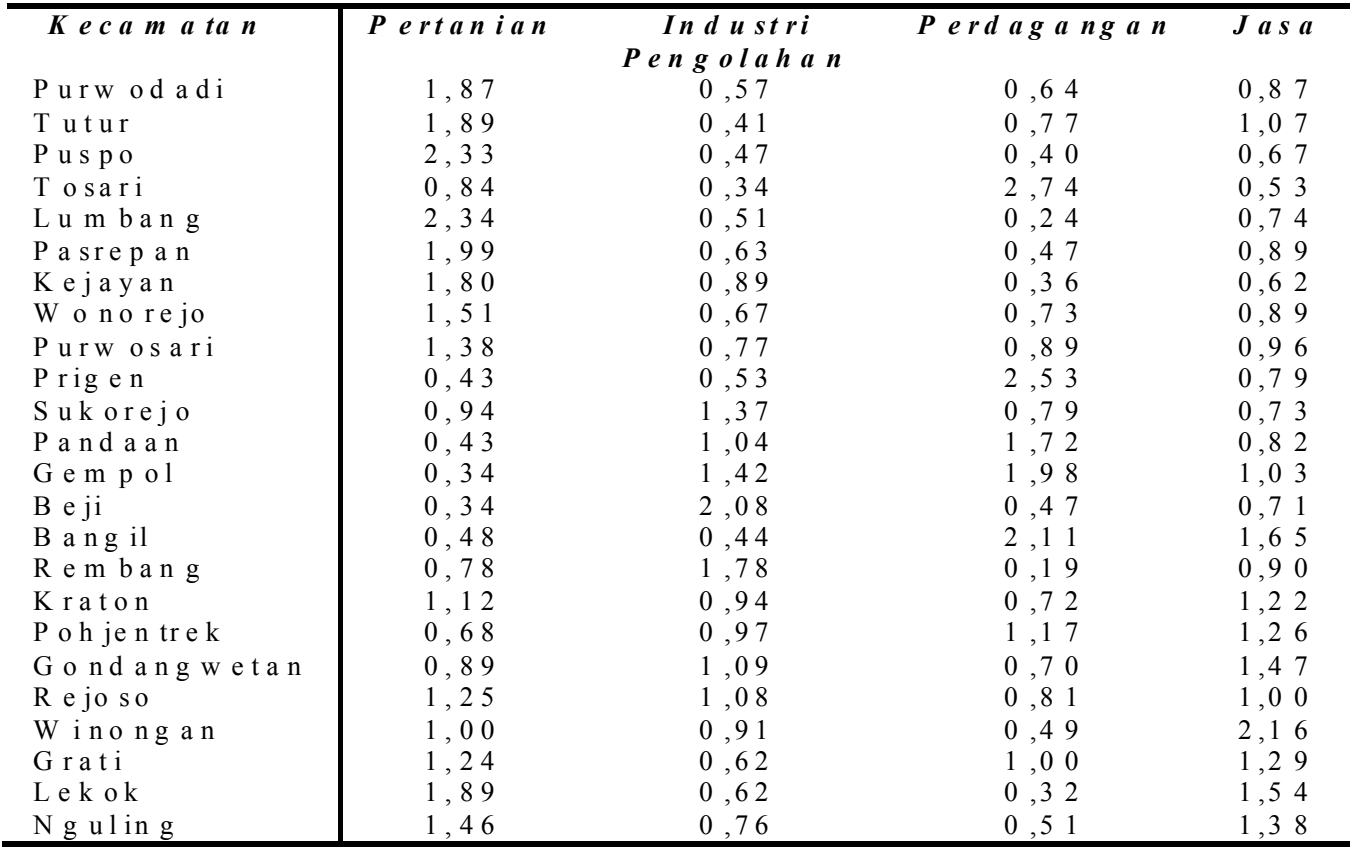

Sumber: Hasil Analisa, 2008 
Analisis Share

Analisis share ini digunakan untuk mengetahui besarnya kontribusi atau proporsi sektor pertanian dalam membentuk total PDRB tiap kecamatan di Kabupaten Pasuruan. Sektor pertanian sendiri berdasarkan hasil LQ memiliki potensi untuk berkembang sehingga potensi tersebut mampu mendukung terhadap rencana pengembangan Pasar Daerah Gempol karena komoditi-komoditi unggulan di sektor pertanian Kabupaten Pasuruan tersebut diharapkan menjadi salah satu komoditi yang dapat ditawarkan atau dipasarkan melalui Pasar Daerah Gempol ini. Perhitungan analisis share ini menggunakan data dalam kurun waktu 5 tahun terakhir.

Berdasarkan hasil perhitungan dapat diketahui bahwa rata-rata nilai share di Kabupaten Pasuruan cukup beragam pada tiap kecamatan. Nilai share tertinggi terdapat pada Kecamatan Puspo dan Kecamatan Lumbang. Hasil tersebut sesuai dengan hasil perhitungan LQ yang menunjukkan bahwa sektor pertanian mendominasi struktur ekonomi pada kedua kecamatan tersebut. Sektor pertanian suatu kecamatan yang potensial disyaratkan harus memiliki nilai share sektor pertanian kecamatan harus lebih tinggi daripada nilai rata-rata share Kabupaten. Nilai rata-rata share sektor pertanian Kabupaten Pasuruan saat ini adalah sebesar 30\%, sehingga diantara kecamatan yang ada terdapat 12 kecamatan dengan nilai share lebih besar daripada nilai share rata-rata Kabupaten Pasuruan. Kondisi tersebut menunjukkan bahwa kontribusi sektor pertanian pada Kabupaten Pasuruan cukup besar dan mendominasi struktur perekonomian Kabupaten Pasuruan. Sedangkan untuk nilai share sektor pertanian yang cukup rendah secara berturut-turut dijumpai pada Kecamatan Gempol, Kecamatan Beji, Kecamatan Bangil, dan Kecamatan Pandaan. Hasil perhitungan analisa share sektor pertanian tiap kecamatan dapat dilihat pada Tabel 6 berikut.

Tabel 6. Analisa Share Sektor Pertanian Kabupaten Pasuruan

\begin{tabular}{|c|c|c|c|c|c|c|}
\hline \multirow{2}{*}{ Keca m ata $n$} & \multicolumn{5}{|c|}{ Ta $\boldsymbol{h} u n$} & \multirow{2}{*}{$\begin{array}{r}R \text { at } a \\
\text { rata }\end{array}$} \\
\hline & 2002 & 2003 & 2004 & 2005 & 2006 & \\
\hline Purw od adi & 51,09 & 55,17 & 48,58 & 50,35 & 47,20 & 50,48 \\
\hline Tutur & 66,04 & 53,65 & 52,04 & 51,72 & 47,67 & 54,23 \\
\hline Puspo & 62,59 & 63,50 & 58,05 & 59,58 & 58,90 & 60,52 \\
\hline Tosari & 39,99 & 27,79 & 25,17 & 24,77 & 21,12 & 27,77 \\
\hline $\mathrm{Lumb}$ a $\mathrm{g}$ & 61,97 & 64,80 & 57,98 & 59,65 & 59,11 & 60,70 \\
\hline Pasrep an & 50,09 & 52,22 & 50,25 & 49,99 & 50,29 & 50,57 \\
\hline $\mathrm{Kej}$ a y $\mathrm{n}$ & 47,51 & 49,25 & 46,50 & 46,34 & 45,36 & 46,99 \\
\hline Wonorejo & 38,75 & 39,13 & 39,63 & 38,20 & 38,15 & 38,77 \\
\hline Purw os a ri & 34.53 & 36.52 & 35,57 & 34.90 & 34,94 & 35.29 \\
\hline Prig e n & 12,18 & 11,15 & 13,25 & 11,24 & 10,81 & 11,72 \\
\hline Suk ore jo & 25,31 & 23,82 & 24,55 & 23,50 & 23,71 & 24,18 \\
\hline$P$ a nd a a n & 12,71 & 11,06 & 12,72 & 11,32 & 10,96 & 11,75 \\
\hline G e m p ol & 8,23 & 9,22 & 8,94 & 8,56 & 8,48 & 8,69 \\
\hline$B$ e ji & 9,10 & 8,86 & 9,32 & 8,65 & 8,57 & 8,90 \\
\hline $\mathrm{B}$ a $\mathrm{ng}$ il & 11,16 & 12,30 & 13,41 & 11,80 & 12,15 & 12,16 \\
\hline $\mathrm{R}$ e $\mathrm{m}$ b a n $\mathrm{g}$ & 19.05 & 21.75 & 20,71 & 20.26 & 19.64 & 20.28 \\
\hline $\mathrm{Kraton}$ & 30,51 & 31,83 & 28,74 & 28,79 & 28,34 & 29,64 \\
\hline Poh je n trek & 15,07 & 17,68 & 18,69 & 17,57 & 17,18 & 17,24 \\
\hline Gond angwetan & 20,62 & 20,63 & 24,84 & 22,03 & 22,39 & 22,10 \\
\hline $\mathrm{R}$ e jo so & 28,68 & 27,14 & 34,36 & 29,58 & 31,63 & 30,28 \\
\hline W ino ng an & 29,64 & 29,08 & 29,29 & 28,19 & 25,24 & 28,29 \\
\hline Grati & 31,26 & 31,27 & 33,13 & 31,17 & 31,42 & 31,65 \\
\hline L e k ok & 47.51 & 50,62 & 49,08 & 49,01 & 47.72 & 48.79 \\
\hline $\mathrm{Ng} \mathrm{u} 1$ in $\mathrm{g}$ & 44,76 & 43,54 & 38,17 & 39,30 & 36,85 & 40,52 \\
\hline
\end{tabular}

Sumber: Hasil Analisa, 2008

\section{Gambaran Umum Pasar Daerah Gempol}

\section{a. Kondisi Fisik}

Pasar Daerah Gempol merupakan salah satu pasar daerah yang manajemen pengelolaannya dikendalikan oleh dinas terkait, yaitu Dinas Pasar Kabupaten Pasuruan. Pasar Daerah Gempol sendiri merupakan pasar dengan klasifikasi kelas II. Secara keseluruhan Pasar Daerah Gempol 
menempati lahan seluas $11.684 \mathrm{~m} 2$ dengan perincian luas kios seluas $1.059,8 \mathrm{~m} 2$ dan luas los seluas 1.602,5 m2. Secara fisik Pasar Daerah Gempol, terdiri dari: los, kios, warung, pasar hewan dan burung, serta fasilitas pelengkap pasar. Berdasarkan data rencana induk pengembangan Pasar Daerah Kabupaten Pasuruan Tahun 2005, bahwa kios yang terdapat pada Pasar Daerah Gempol adalah berjumlah 205 unit yang terdiri dari 175 unit kios permanen dan 26 unit kios non permanen. Adapun kondisi kios, toko, maupun los yang ada di Pasar Daerah Gempol dapat dilihat pada gambar berikut ini.
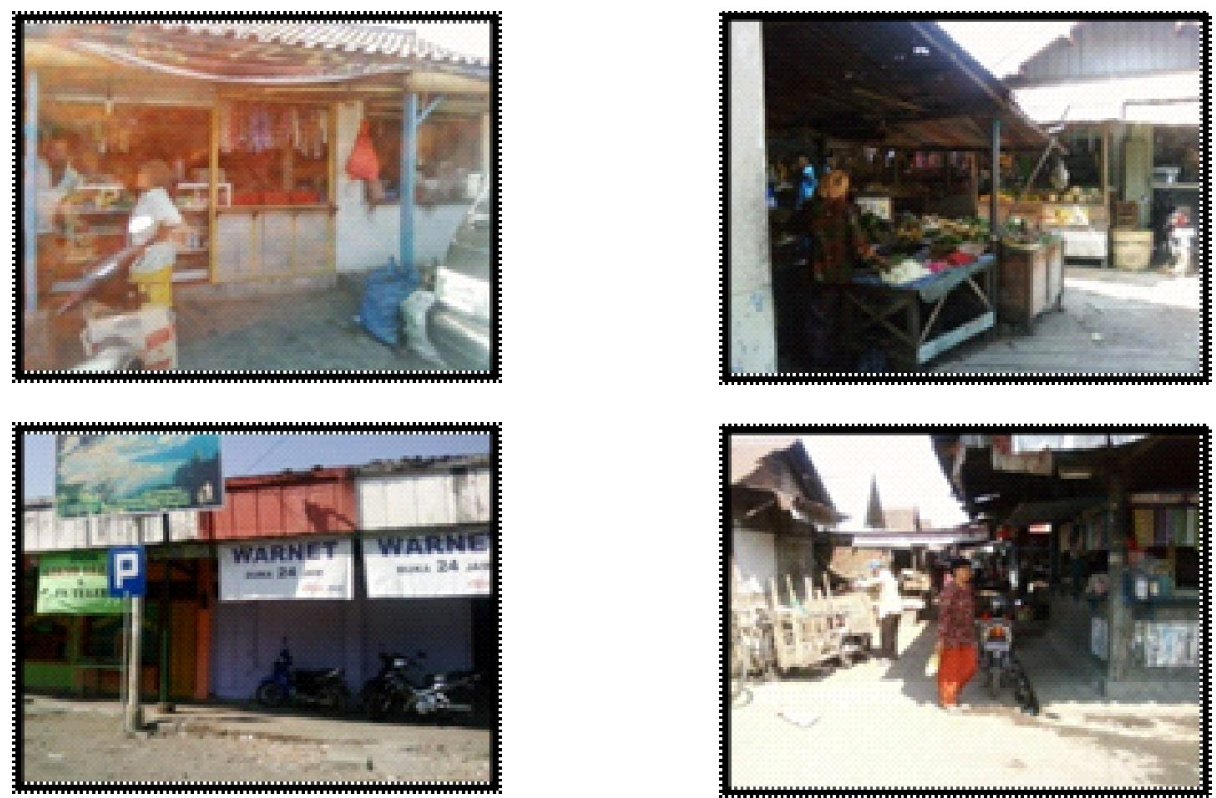

\section{Gambar 3. Kondisi Kios, Toko, dan Los pada Pasar Daerah Gempol}

Prasarana pendukung yang ada pada Pasar Daerah Gempol, antara lain: jaringan listrik, air bersih, drainase, dan sampah. Fasilitas listrik dibutuhkan oleh semua pengguna Pasar Daerah Gempol untuk mendukung aktivitas perdagangan, baik pada pagi maupun siang hari. Kebutuhan listrik pada Pasar Daerah Gempol dipenuhi oleh PLN. Kemudian untuk kebutuhan air bersih dipenuhi dari jaringan PDAM serta sumur yang berada dalam lingkungan Pasar Daerah Gempol. Air bersih ini diperlukan terutama oleh pedagang ayam potong, daging, dan ikan dengan tujuan selain supaya barang dagangannya tetap bersih, air bersih tersebut juga dipergunakan untuk keperluan lain.

Jaringan drainase pada Pasar Daerah Gempol berfungsi untuk mendukung penanganan air kotor/ limbah akibat aktivitas perdagangan maupun non-perdagangan. Kondisi jaringan drainase tersebut saat ini cukup buruk karena selain banyak saluran yang tersumbat oleh sampah juga banyak saluran yang kondisinya rusak. Fungsi jaringan drainase ini sangat penting karena menyalurkan air limbah maupun air hujan yang ada dalam Pasar Daerah Gempol, karenanya usaha untuk memperbaiki jaringan drainase pada Pasar Daerah Gempol sangat diperlukan.

Penanganan sampah pada Pasar Daerah Gempol saat ini dilakukan oleh petugas kebersihan. Sampah dikumpulkan oleh petugas dari setiap toko atau kios yang ada dalam pasar kemudian dibuang ke TPS. Walaupun pada pasar terdapat fasilitas TPS, akan tetapi masih banyak para pengguna pasar yang membuang sampah secara sembarangan sehingga mengotori pasar dan seringkali sampahsampah tersebut menyumbat saluran drainase yang ada.

Berdasarkan kondisi eksisting, bahwa pada saat ini Pasar Daerah Gempol lebih berfungsi sebagai pasar konsumsi (tempat pemenuhan kebutuhan sehari-hari). Kondisi bangunan di dalam pasar didominasi oleh los yang menjual barang-barang kebutuhan sehari-hari, seperti: sembako, sayur, maupun bahan makanan lainnya. Selain itu, juga terdapat beberapa bangunan pasar yang difungsikan sebagai rumah tinggal. Adapun kondisi beberapa bangunan pada Pasar Daerah Gempol yang juga difungsikan sebagai rumah tinggal dapat dilihat pada gambar berikut ini. 

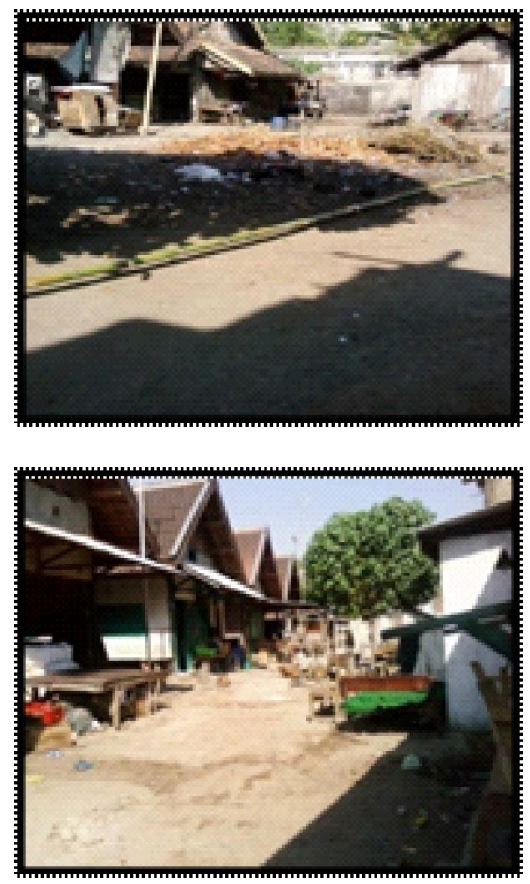
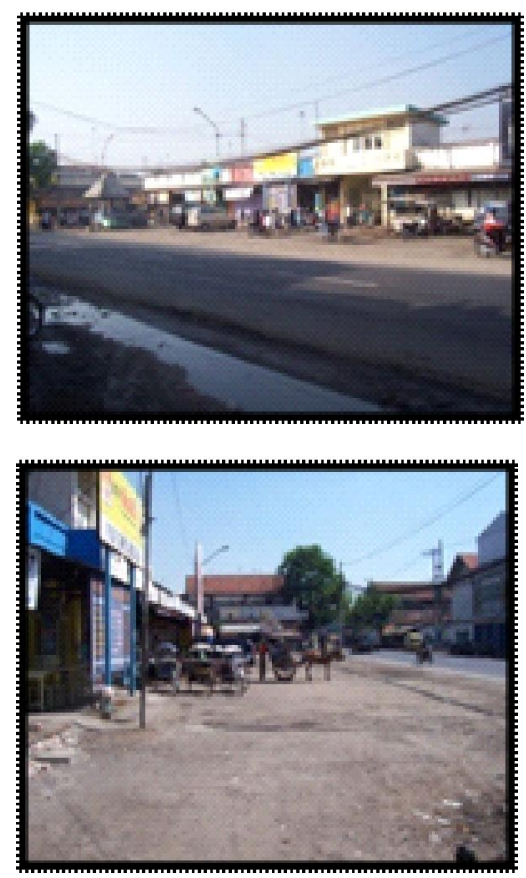

Gambar 4. Kondisi Bagian Pasar yang difungsikan sebagai Tempat Tinggal Aksesibilitas

Aksesibilitas disini membahas sirkulasi internal dan sirkulasi eksternal yang akan diuraikan sebagai berikut :

a. Sirkulasi Internal

Sirkulasi internal pada Pasar Daerah Gempol saat ini terlihat masih semrawut atau belum tertata secara teratur. Hal ini diindikasikan oleh adanya jalur untuk pejalan kaki dan kendaraan yang berada dalam kawasan pasar. Berdasar kondisi eksisting, sirkulasi internal Pasar Daerah Gempol terdiri dari area parkir yang terletak di bagian depan pasar, jalan tembus yang menghubungkan jalan Surabaya-Malang dengan jalan Surabaya-Bangil, serta jalur pejalan kaki yang terletak di bagian dalam pasar. Kondisi perkerasan area parkir Pasar Daerah Gempol saat ini sebagian masih tanah dan makadam sehingga kurang mendukung aktivitas sirkulasi internal Pasar Daerah Gempol. Area parkir Pasar Daerah Gempol tidak hanya dimanfaatkan untuk parkir kendaraan bermotor akan tetapi juga andong maupun becak. Untuk lebih jelasnya informasi tersebut dapat dilihat pada gambar berikut ini.
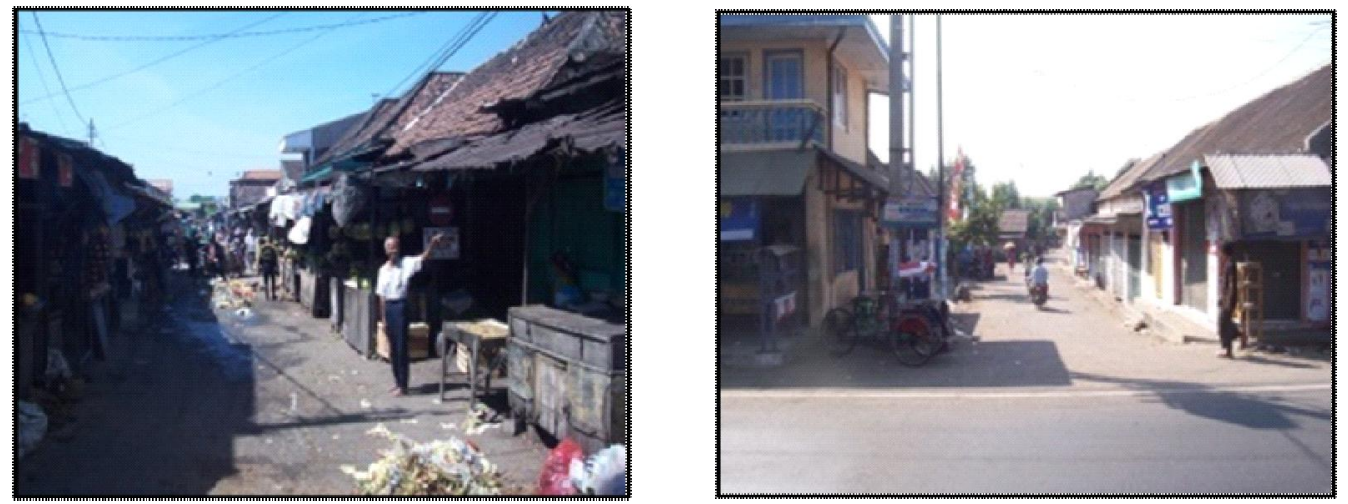

Gambar 5. Kondisi Area Parkir Pasar Daerah Gempol 
Jalan tembus penghubung antara jalan Surabaya-Malang dengan jalan Surabaya-Bangil merupakan bagian dari site Pasar Daerah Gempol yang bertujuan untuk memperlancar sirkulasi kendaraan didalam pasar serta jalur untuk mencapai pasar hewan yang lokasinya di belakang bangunan pasar. Kondisi jalan tembus saat ini mengalami kerusakan dibeberapa bagian yang disebabkan oleh adanya beberapa kendaraan yang melewati jalan ini muatan yang sangat berat.

Sementara itu, jalur yang merupakan bagian sirkulasi internal adalah jalur pejalan kaki yang letaknya berada dalam bangunan pasar. Jalur pejalan kaki ini kondisinya kurang baik dan sangat kurang mendukung aktivitas dalam pasar, dimana pada beberapa bagian terlihat becek, kotor, serta pada bagian yang lain mengalami kerusakan. Kondisi sirkulasi internal Pasar Daerah Gempol sangat memprihatinkan, sehingga dibutuhkan adanya perhatian yang serius dari pihak pengelola apabila kedepan Pasar Daerah Gempol diharapkan fungsi dan aktivitasnya meningkat.

b. Sirkulasi Eksternal

Sirkulasi eksternal Pasar Daerah Gempol ini adalah jaringan jalan yang berada di wilayah sekitar pasar yang dapat berfungsi sebagai sarana pencapaian menuju lokasi pasar. Posisi Pasar Daerah Gempol sangat strategis, karena pasar tersebut terletak pada jalur arteri primer, yaitu SurabayaMalang-Jawa Timur bagian selatan, dan Surabaya-Bangil-Probolinggo-Bali. Posisi ini memiliki pengaruh penting dalam mendukung perkembangan Pasar Daerah Gempol. Kondisi jaringan jalan yang ada disekitar Pasar Daerah Gempol cukup mendukung aktivitas transportasi yang melewatinya. Seluruh jaringan jalan yang ada saat ini diperkeras dengan aspal hotmix sehingga kondisinya cukup baik.

Keberadaan Pasar Daerah Gempol dengan posisi yang berada pada jalur arteri primer maka diperkirakan perkembangan aktivitas Pasar Daerah Gempol tersebut akan berdampak terhadap kondisi lalu lintas yang ada di sekitarnya, sehingga dalam perencanaan kedepan kondisi lalu lintas harus diantisipasi mengingat dengan adanya peningkatan fungsi maka akan meningkatkan aktivitas pegerakan penduduk sehingga bangkitan dan tarikan pergerakan pada Pasar Daerah Gempol tersebut menjadi lebih tinggi. Selain itu, dengan adanya rencana pembangunan jalan tol maka posisi Pasar Daerah Gempol semakin strategis karena memiliki jarak yang cukup dekat dengan jalur tol menuju Surabaya sehingga paling tidak akan memberikan akses yang cukup luas menuju Pasar Daerah Gempol ini.

Sebagai jaringan jalan dengan fungsi yang penting maka jaringan jalan di sekitar wilayah Pasar Gempol memiliki aktvitas pergerakan yang cukup tinggi. Kondisi jaringan jalan di sekitar wilayah Pasar Gempol sebagai aspek sirkulasi eksternal digambarkan dengan kondisi lalu lintas tersebut. Adapun informasi mengenai kondisi lalu lintas pada jaringan jalan di sekitar Pasar Daerah Gempol pada saat hari sibuk (hari senin - hari kamis) dapat dilihat pada Tabel 7 sedangkan kondisi lalu lintas pada saat hari biasa dapat dilihat pada Tabel 8 berikut ini.

Tabel 7. Volume Lalu Lintas di Sekitar Pasar Daerah Gempol Senin-Kamis

\begin{tabular}{|c|c|c|c|c|c|c|c|c|}
\hline Jalur & $\begin{array}{l}\text { Sepeda } \\
\text { Motor }\end{array}$ & Mobil & Angkot & $\underset{\text { Besar }}{\text { Bus }}$ & $\begin{array}{c}\text { Bus } \\
\text { Kecil }\end{array}$ & $\begin{array}{c}\text { Truk } \\
\text { Besar }\end{array}$ & $\begin{array}{l}\text { Truk } \\
\text { Kecil }\end{array}$ & $\begin{array}{l}\text { Non } \\
\text { Motor }\end{array}$ \\
\hline \multicolumn{9}{|l|}{ Suraba ya -P asuruan } \\
\hline $\mathrm{Pagi}(07.00-08.00)$ & 777 & 225 & 31 & 9 & 40 & 10 & 65 & 54 \\
\hline Siang $(12.00-13.00)$ & 651 & 183 & 25 & 10 & 28 & 13 & 55 & 49 \\
\hline Sore $(17.00-18.00)$ & 467 & 157 & 6 & 5 & 12 & 2 & 26 & 13 \\
\hline \multicolumn{9}{|l|}{ Suraba ya $-M$ alang } \\
\hline Pa gi $(07.00-08.00)$ & 2241 & 334 & 54 & 52 & 83 & 27 & 76 & 15 \\
\hline Siang $(12.00-13.00)$ & 1558 & 436 & 56 & 61 & $\begin{array}{c}11 \\
2\end{array}$ & 48 & $\begin{array}{c}11 \\
0\end{array}$ & 9 \\
\hline Sore $(17.00-18.00)$ & 1552 & 345 & 30 & 34 & 57 & 35 & 65 & 12 \\
\hline \multicolumn{9}{|l|}{ M alang-S u ra bay a } \\
\hline Pagi (07.00-08.00) & 2347 & 359 & 66 & 46 & 71 & 31 & 53 & 25 \\
\hline
\end{tabular}


Lanjutan Tabel 7. Volume Lalu Lintas di Sekitar Pasar Daerah Gempol Senin-Kamis

\begin{tabular}{l|cccccccc}
\hline \multicolumn{1}{c|}{ Jalur } & $\begin{array}{c}\text { Sepeda } \\
\text { Motor }\end{array}$ & Mobil & Angkot & $\begin{array}{c}\text { Bus } \\
\text { Besar }\end{array}$ & $\begin{array}{c}\text { Bus } \\
\text { Kecil }\end{array}$ & $\begin{array}{c}\text { Truk } \\
\text { Besar }\end{array}$ & $\begin{array}{c}\text { Truk } \\
\text { Kecil }\end{array}$ & $\begin{array}{c}\text { Non } \\
\text { Motor }\end{array}$ \\
\hline Siang (12.00-13.00) & 1712 & 407 & 52 & 73 & 86 & 33 & 50 & 12 \\
Sore (17.00-18.00) & 1503 & 413 & 15 & 26 & 34 & 23 & 24 & 2 \\
Pasuruan-Surabaya & & & & & & & & \\
Pagi (07.00-08.00) & 837 & 426 & 26 & 2 & 33 & 7 & 17 & 53 \\
Siang (12.00-13.00) & 712 & 298 & 21 & 3 & 32 & 5 & 13 & 35 \\
Sore (17.00-18.00) & 501 & 129 & 7 & - & 25 & 2 & 4 & 11 \\
\hline
\end{tabular}

Sumber: Hasil Survey Primer, 2008

Tabel 8. Volume Lalu Lintas di sekitar Pasar Daerah Gempol Jumat-Minggu

\begin{tabular}{|c|c|c|c|c|c|c|c|c|}
\hline Jalur & $\begin{array}{l}\text { Sepeda } \\
\text { Motor }\end{array}$ & Mo bil & Angkot & $\begin{array}{c}\text { Bus } \\
\text { Besar }\end{array}$ & $\begin{array}{l}\text { Bus } \\
\text { Kecil }\end{array}$ & $\begin{array}{l}\text { Truk } \\
\text { B esar }\end{array}$ & $\begin{array}{l}\text { Truk } \\
\text { Kecil }\end{array}$ & $\begin{array}{l}\text { Non } \\
\text { Mo tor }\end{array}$ \\
\hline \multicolumn{9}{|l|}{ S u rab ay a-P a surua $n$} \\
\hline Pag i ( $07.00-08.00)$ & 771 & 897 & 23 & 6 & 44 & 2 & 51 & 24 \\
\hline Siang $(12.00-13.00)$ & 777 & 1048 & 19 & 15 & 48 & 5 & 41 & 13 \\
\hline Sore $(17.00-18.00)$ & 643 & 669 & 13 & 10 & 52 & 7 & 42 & 19 \\
\hline \multicolumn{9}{|l|}{ Su rab ay a-M ala ng } \\
\hline $\mathrm{Pag}$ i $(07.00-08.00)$ & 2150 & 687 & 45 & 7 & 58 & 15 & 6 & 4 \\
\hline Siang $(12.00-13.00)$ & 1123 & 879 & 49 & 22 & 61 & 21 & 22 & 1 \\
\hline Sore $(17.00-18.00)$ & 1439 & 982 & 43 & 23 & 75 & 24 & 8 & 6 \\
\hline \multicolumn{9}{|l|}{ M al ang-Surabaya } \\
\hline $\mathrm{Pag} i(07.00-08.00)$ & 1431 & 701 & 32 & 47 & 70 & 27 & 29 & 4 \\
\hline Siang $(12.00-13.00)$ & 895 & 850 & 53 & 50 & 89 & 31 & 20 & 8 \\
\hline Sore $(17.00-18.00)$ & 1137 & 929 & 42 & 44 & 66 & 31 & 25 & 5 \\
\hline \multicolumn{9}{|l|}{ P asuruan-S u rab ay a } \\
\hline Pag i ( $07.00-08.00)$ & 1078 & 659 & 40 & 4 & 60 & 2 & 45 & 17 \\
\hline Siang $(12.00-13.00)$ & 810 & 449 & 29 & 5 & 48 & 5 & 38 & 4 \\
\hline Sore $(17.00-18.00)$ & 1184 & 409 & 12 & 2 & 50 & 2 & 51 & 5 \\
\hline
\end{tabular}

Berdasarkan pada tabel diatas diketahui bahwa jalur yang paling padat dan tinggi aktivitas lalu lintasnya adalah jalur Surabaya-Malang dan Malang-Surabaya. Kondisi tersebut disebabkan jalur tersebut merupakan jalur penghubung antara Kota Surabaya dengan wilayah lain di bagian selatan Jawa Timur sehingga banyak kendaraan yang melewati jalur ini menuju Kota Surabaya dan sebaliknya. Sementara itu, waktu dengan volume lalu lintas tertinggi pada jaringan jalan sekitar Pasar Daerah Gempol adalah dijumpai pada jam-jam pagi saat hari sibuk, yaitu hari senin sampai kamis dengan aktivitas lalu lintas pada jaringan jalan sekitar Pasar Daerah Gempol didominasi oleh kendaraan sepeda motor daripada jenis moda yang lain. Kondisi lalu lintas yang tinggi tersebut menunjukkan bahwa pada wilayah Pasar Daerah Gempol merupakan wilayah yang cukup strategis bila ditinjau dari aspek transportasinya. Secara visual informasi diatas dapat dilihat pada gambar gambar berikut ini. 

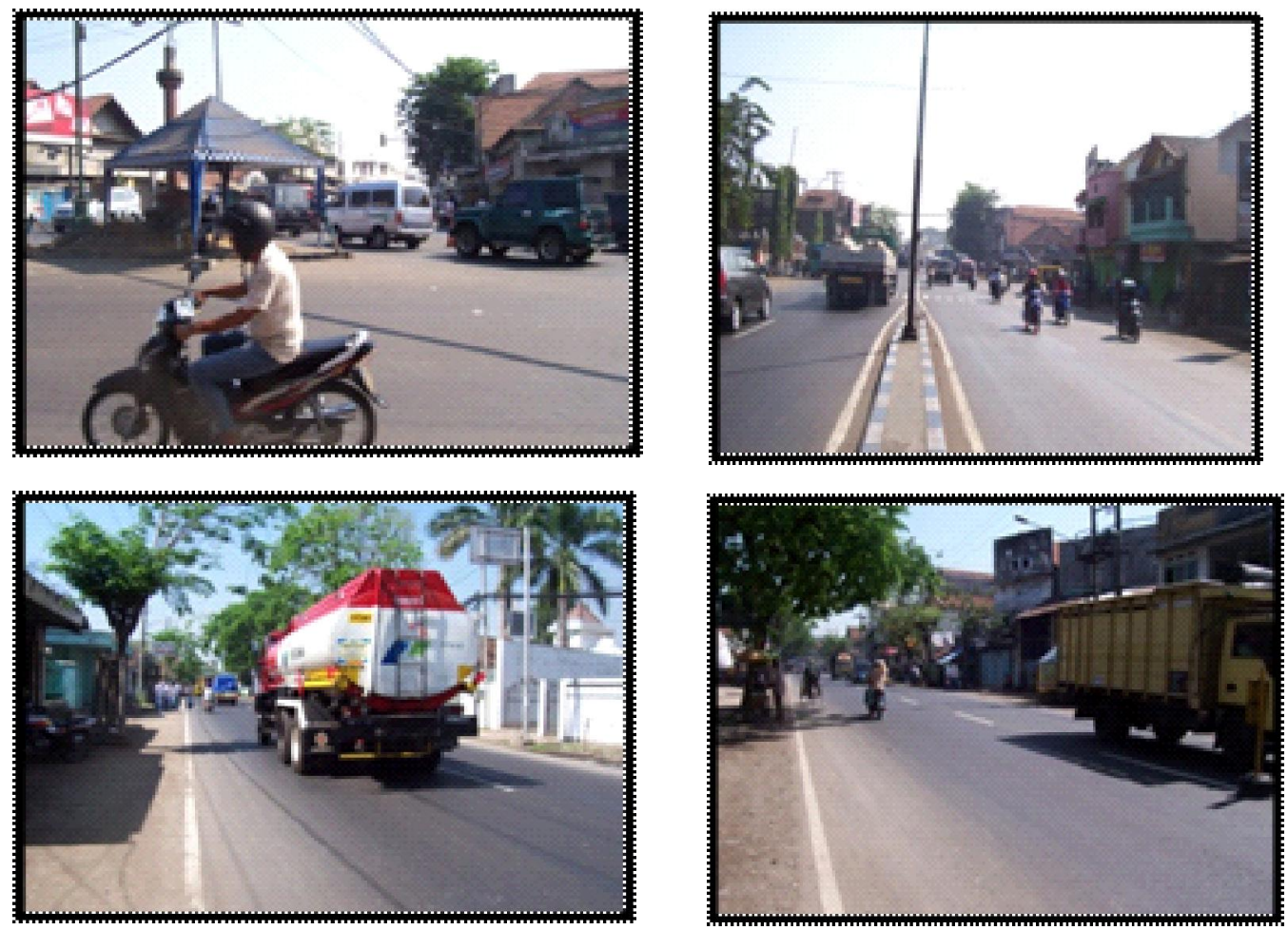

Gambar 5. Kondisi Jalur Surabaya-Malang disekitar Pasar Daerah Gempol (atas) dan Kondisi Jalur Surabaya-Pasuruan disekitar Pasar Gempol (bawah)

Selanjutnya untuk gambaran mengenai kondisi ruang Pasar daerah Gempol dapat dilihat pada Peta (gambar 6).

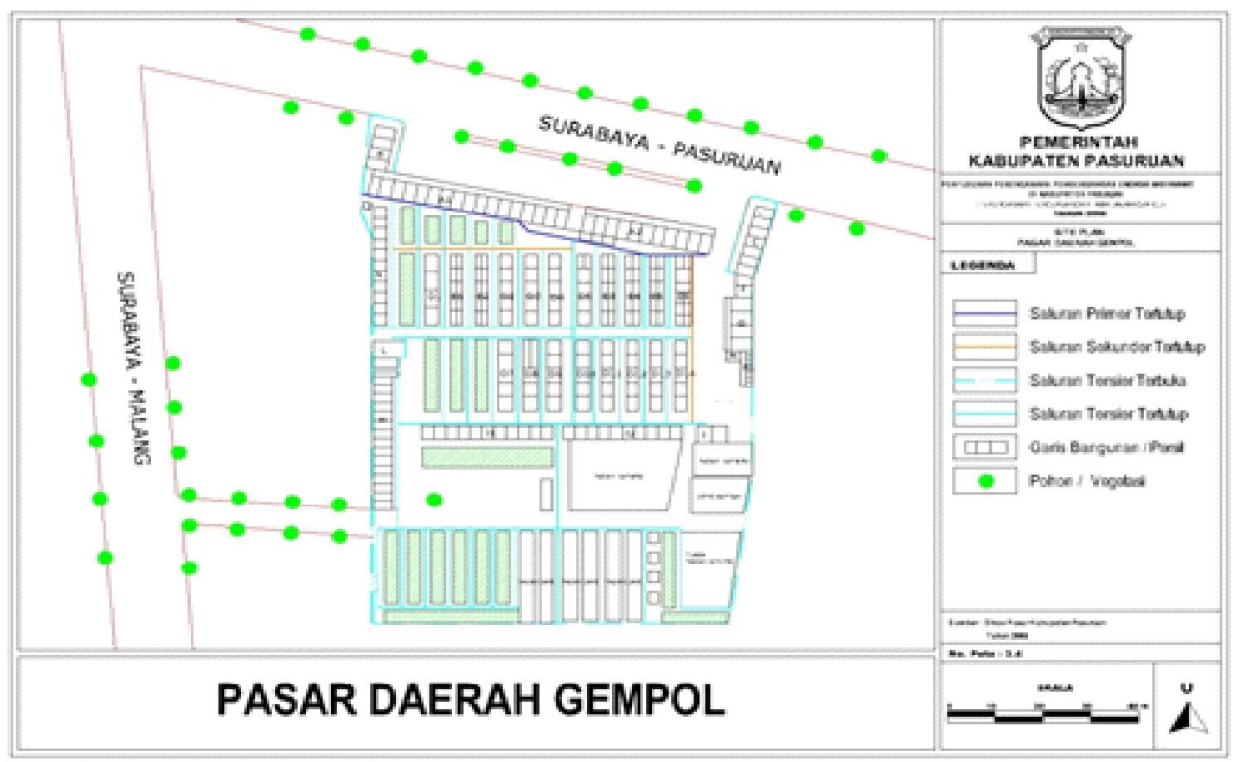

Gambar 6. Kondisi Ruang Pasar Daerah Gempol 


\section{Analisis Multiplier Effect}

Pengembangan Pasar Daerah Gempol pada dasarnya merupakan pengembangan sektor perdagangan karena sektor perdagangan pada Kecamatan Gempol memiliki kontribusi yang cukup besar terhadap PDRB. Kecamatan Gempol bersama Kecamatan Bangil, Kecamatan Beji, dan Kecamatan Pandaan juga merupakan sentra industri kecil unggulan Kabupaten Pasuruan. Apabila kedua sektor tersebut memiliki korelasi yang cukup kuat maka pertumbuhan aktivitas perdagangan diharapkan mampu mempengaruhi pertumbuhan aktivitas sektor industri kecil. Pengembangan Pasar Daerah Gempol dapat dijadikan sebagai salah satu generator pendukung perkembangan sektor industri mikro, kecil, dan menengah Kabupaten Pasuruan, dimana Pasar Daerah Gempol berfungsi sebagai sentra pemasaran dan promosi produk-produk yang dihasilkan dari aktivitas industri kecil dan menengah serta lokasi pemenuhan bahan baku untuk industri tersebut.

Promosi dan pemasaran produk-produk unggulan industri mikro, kecil, dan menengah dapat dilakukan secara terpadu oleh pemerintah daerah Kabupaten Pasuruan melalui penyediaan toko dan kios serta kegiatan pameran pada Pasar Daerah Gempol. Fungsi sebagai lokasi pemenuhan bahan baku industri ditujukan untuk membantu para pelaku industri mikro, kecil, dan menengah agar lebih mudah untuk mendapatkan bahan baku yang giliran selanjutnya mampu menekan biaya produksi. Kedua rencana fungsi Pasar Daerah Gempol tersebut diharapkan mampu untuk mendukung dan menjaga perkembangan sektor industri mikro, kecil, dan menengah Kabupaten Pasuruan. Mengingat lokasi Pasar Daerah Gempol terletak pada jalur transportasi regional maka diperkirakan akan memudahkan masyarakat di luar Kabupaten Pasuruan untuk mencapai Pasar Daerah Gempol.

Selanjutnya untuk melihat potensi multiplier effect dari aspek ekonomi dapat ditinjau dengan beberapa perhitungan ekonomi basis. Dengan mengasumsikan bahwa perkembangan sektor perdagangan dan industri adalah sebagai sektor basis, maka untuk menunjukkan tingkat pengaruh kegiatan pengembangan Pasar Daerah Gempol terhadap kondisi perekonomian wilayah sekitarnya (meliputi Kecamatan Gempol, Kecamatan Bangil, Kecamatan Beji, dan Kecamatan Bangil) dilakukan prediksi dalam beberapa tahun. Prediksi perkembangan sektor basis tersebut dihitung atas dasar nilai koefisien penggandaan (M). Rumus untuk perhitungan pengganda pendapatan sektor basis dapat dilihat pada rumus berikut:

$$
M=\frac{Y}{Y B}
$$

Dengan:

M = Penggandaan Pendapatan Sektor Basis

$\mathrm{Y}=$ Pendapatan Total

$\mathrm{YB}=$ Pendapatan Basis

Berdasarkan perhitungan pengganda pendapatan sektor basis tersebut selanjutnya dapat diperoleh informasi seperti yang ditunjukkan pada Tabel 9 berikut ini.

Tabel 9. Pengganda Pendapatan Sektor Perdagangan

\begin{tabular}{c|cccc}
\hline Tahun & $\boldsymbol{Y}$ & $\boldsymbol{Y B}$ & $\boldsymbol{M}$ & $\boldsymbol{?} \boldsymbol{Y B}$ \\
\hline 2002 & $409.053,32$ & $72.471,65$ & 5,6443 & - \\
2003 & $429.178,59$ & $75.725,73$ & 5,6675 & $3.254,08$ \\
2004 & $456,568,45$ & $80.097,28$ & 5,7002 & $4.371,55$ \\
2005 & $485.687,05$ & $84.531,81$ & 5,7456 & $4.434,53$ \\
2006 & $518.688,93$ & $90.646,63$ & 5,7221 & $6.114,82$ \\
\hline
\end{tabular}

Sumber : Data Sekunder Diolah, Tahun 2008

Berdasar perhitungan pada Tabel 3, diketahui bahwa perkembangan sektor perdagangan sebagai sektor yang berkorelasi cukup erat dengan pengembangan Pasar Daerah Gempol menunjukkan tren yang positif. Nilai pengganda sektor perdagangan Kecamatan Gempol juga cukup besar berkisar 5,6-5,7. Hal tersebut berarti bahwa setiap Rp. 1,- pendapatan yang diperoleh dari sektor perdagangan akan menghasilkan sekitar Rp. 5,00 - Rp. 6,00 pendapatan wilayah Kecamatan Gempol. Prediksi 
perkembangan sektor perdagangan pada Kecamatan Gempol akan semakin besar mengingat intensitas dan lapangan pekerjaan pada sektor ini juga semakin meningkat akibat adanya kegiatan pembangunan Pasar Daerah Gempol.

Sektor industri pengolahan pada wilayah kajian (Kecamatan Bangil, Beji, Gempol, dan Pandaan) merupakan sektor memiliki potensi untuk berkembang. Meskipun kontribusi terhadap total pendapatan tiap kecamatan tidak terlalu dominan akan tetapi tingkat perkembangannya cukup menjanjikan. Perhitungan nilai pengganda sebagai indikator potensi multiplier effect pada sektor industri wilayah kajian dapat dilihat pada Tabel 10. sampai dengan Tabel 13.

Tabel. 10. Pengganda Pendapatan Sektor Industri Pengolahan Kecamatan Bangil

\begin{tabular}{c|cccc}
\hline $\boldsymbol{T a} \boldsymbol{h} \boldsymbol{u} \boldsymbol{n}$ & $\boldsymbol{Y}$ & $\boldsymbol{Y B}$ & $\boldsymbol{M}$ & $\boldsymbol{?} \boldsymbol{Y B}$ \\
\hline 2002 & $275.082,41$ & $34.779,74$ & 7,9093 & - \\
2003 & $287.079,14$ & $36.338,62$ & 7,9001 & $5.649,20$ \\
2004 & $271.597,21$ & $38.790,39$ & 7,0017 & $9.104,63$ \\
2005 & $298.160,61$ & $41.348,60$ & 7,2109 & $9.252,60$ \\
2006 & $311.789,08$ & $44.102,71$ & 7,0696 & $9.602,19$ \\
\hline
\end{tabular}

Sumber: Data Sekunder Diolah, Tahun 2008

Tabel 11. Pengganda Pendapatan Sektor Industri Pengolahan Kecamatan Beji

\begin{tabular}{c|cccc}
\hline $\boldsymbol{T} \boldsymbol{a} \boldsymbol{h} \boldsymbol{u} \boldsymbol{n}$ & $\boldsymbol{Y}$ & $\boldsymbol{Y B}$ & $\boldsymbol{M}$ & $\boldsymbol{?} \boldsymbol{Y B}$ \\
\hline 2002 & $394.819,42$ & $260.196,69$ & 1,5174 & - \\
2003 & $416.677,13$ & $274.643,62$ & 1,5172 & $14.446,93$ \\
2004 & $441.023,34$ & $289.835,16$ & 1,5216 & $15.191,54$ \\
2005 & $465.585,98$ & $308.949,18$ & 1,5070 & $19.114,02$ \\
2006 & $496.642,79$ & $329.774,06$ & 1,5060 & $20.824,88$ \\
\hline
\end{tabular}

Sumber: Data Sekunder Diolah, Tahun 2008

Tabel 12. Pengganda Pendapatan Sektor Industri Pengolahan Kecamatan Gempol

\begin{tabular}{c|cccc}
\hline Tahun & $\boldsymbol{Y}$ & $\boldsymbol{Y B}$ & $\boldsymbol{M}$ & $\boldsymbol{P} \boldsymbol{Y B}$ \\
\hline 2002 & $409.053,32$ & $174.730,65$ & 2,3411 & - \\
2003 & $429.178,59$ & $185.287,41$ & 2,3163 & $10.556,76$ \\
2004 & $456,568,45$ & $201.145,94$ & 2,2698 & $15.858,53$ \\
2005 & $485.687,05$ & $217.616,44$ & 2,2318 & $16.470,50$ \\
2006 & $518.688,93$ & $235.006,90$ & 2,2071 & $17.390,46$ \\
\hline
\end{tabular}

Sumber: Data Sekunder Diolah, Tahun 2008

Tabel 13. Pengganda Pendapatan Sektor Industri Pengolahan Kecamatan Pandaan

\begin{tabular}{c|cccc}
\hline Tahun & $\boldsymbol{Y}$ & $\boldsymbol{Y B}$ & $\boldsymbol{M}$ & $\boldsymbol{?} \boldsymbol{Y B}$ \\
\hline 2002 & $352.922,18$ & $110.131,49$ & 3,2046 & - \\
2003 & $367.310,01$ & $115.780,69$ & 3,1725 & $5.649,20$ \\
2004 & $388.008,41$ & $124.885,32$ & 3,1069 & $9.104,63$ \\
2005 & $410.140,34$ & $134.137,92$ & 3,0576 & $9.252,60$ \\
2006 & $433.748,51$ & $143.740,11$ & 3,0176 & $9.602,19$ \\
\hline
\end{tabular}

Sumber: Data Sekunder Diolah, Tahun 2008 


\section{Journal of Indonesian Applied Economics}

Vol. 3 No. 2 Oktober 2009, 178-199

Pada Tabel 10. sampai dengan Tabel 13 menunjukkan bahwa nilai pengganda sektor industri pada Kecamatan Beji, Gempol, dan Pandaan masih berada dibawah nilai pengganda sektor perdagangan Kecamatan Gempol. Hal ini apabila Pasar Daerah Gempol dikembangkan, bahwa nilai pengganda sektor perdagangan Kecamatan Gempol juga akan berkembang sehingga akan memacu peningkatan nilai pengganda sektor industri pada wilayah sekitarnya. Sektor perdagangan dan sektor industri pada kegiatan pengembangan Pasar Daerah Gempol ini memiliki korelasi yang besar karena dengan adanya kegiatan ini diharapkan Pasar Daerah Gempol tidak hanya dijadikan pasar konsumsi harian saja tetapi juga dapat dijadikan sebagai pusat pemasaran produk-produk unggulan hasil aktivitas industri Kabupaten Pasuruan. Dengan adanya peningkatan nilai pengganda diatas 5 (lima), maka diharapkan terjadi peningkatan pendapatan pada sektor-sektor basis terutama sektor perdagangan dan sektor industri.

Nilai pengganda sektor industri paling tinggi terjadi di Kecamatan Bangil yaitu sekitar 7,9. Sehingga setiap Rp. 1,- pendapatan sektor industri pengolahan Kecamatan Bangil akan mendorong peningkatan pendapatan wilayahnya menjadi Rp. 8,-. Hal ini dapat dikatakan bahwa sektor industri di Kecamatan Bangil memiliki potensi yang sangat besar untuk dapat berkembang. Salah satu produk sektor industri pengolahan pada wilayah kajian yang berpotensi menjadi produk unggulan Kabupaten Pasuruan adalah kerajinan bordir dan produk konveksi.

Analisis SWOT

Analisis SWOT adalah analisis mengenai potensi (strength), masalah (weakness), kesempatan (opportunity) dan ancaman (threat) yang terdapat pada pengembangan Pasar Daerah Gempol. SWOT merupakan salah satu teknik analisis yang digunakan dalam menginterpretasikan wilayah studi, khususnya pada kondisi yang sangat kompleks dengan faktor internal dan eksternal memegang peranan yang sangat penting. Potensi yang dapat dikembangkan dan permasalahan yang dapat diatasi untuk mendukung pengembangan Pasar Daerah Gempol dijadikan dasar dalam analisis SWOT.

Tabel.14. SWOT Pengembangan Pasar Daerah Gempol

\begin{tabular}{|c|c|c|}
\hline & In ternal & Eksternal \\
\hline - & $\begin{array}{l}\text { Kekuatan (Strength) } \\
\text { Lokasi Pasar Daerah G em pol } \\
\text { yang strategis } \\
\text { Kabupaten Pasuruan memiliki } \\
\text { produk ataukomoditi potensial } \\
\text { yang la yak dikembangkan, } \\
\text { terutamabordirdankerajinan } \\
\text { perak } \\
\text { Pedagang sangat mendukung } \\
\text { rencana pengem a ngan Pasar } \\
\text { Daerah Gempol } \\
\text { Kelemahan (Weakness) }\end{array}$ & $\begin{array}{l}\text { - } \quad \text { Besempatan (Opportunity) } \\
\text { B elum adanya pasar } \\
\text { untuk memasarkan } \\
\text { produk unggulan } \\
\text { Kabupaten Pasuruan } \\
\text { - A danyarencana } \\
\text { pengalihan jalantol } \\
\text { M andeknya aktivitas } \\
\text { Pasar Tanggulangin } \\
\text { s ebagai sentra produk } \\
\text { unggulan Kab. Sidoarjo } \\
\text { Ancaman (Threat) }\end{array}$ \\
\hline - & $\begin{array}{l}\text { Pasar Gempolsaat in kurang } \\
\text { dikenal dan diminati } \\
\text { ma syarakat } \\
\text { Kondisi fisik Pasar Da erah } \\
\text { Gempolyangkurang layak } \\
\text { sehing ga kurang mendukung } \\
\text { aktivitas perdagangan } \\
\text { Banyak pem ilik industri lebih } \\
\text { memilih mendapatkan bahan } \\
\text { bakudariluar Kab. Pasuruan }\end{array}$ & $\begin{array}{l}\text { - A danyabencana banjir } \\
\text { - } \quad \text { Ampur Sidoarjo } \\
\text { pengembangan Kec. } \\
\text { Porong sebagai pusat } \\
\text { perdagangan wilayah } \\
\text { s elatan Kab. Sidoarjo } \\
\text { B erdasarkebijakan } \\
\text { pengembangan } \\
\text { Kabupaten Pasuruan, } \\
\text { Kec. Gem pol hany } \\
\text { berfungsi sebagaipusat } \\
\text { pelayanan lokal }\end{array}$ \\
\hline
\end{tabular}




\section{Fungsi Pasar Daerah Gempol}

Pasar Daerah Gempol sesuai dengan fungsi yang dibebankan pada Kecamatan Gempol memiliki fungsi yaitu sebagai pusat pelayanan lokal dengan wilayah pelayanan meliputi 1 kecamatan. Untuk itu dalam pelaksanaannya, fasilitas-fasilitas yang ada di Kecamatan Gempol tidak hanya melayani kebutuhan penduduk Kecamatan Gempol akan tetapi juga kebutuhan penduduk wilayah kecamatan lain yang berdekatan dengan Kecamatan Gempol seperti Kecamatan Porong, Kecamatan Ngoro, dan Kecamatan Beji. Kondisi tersebut membuat fungsi Kecamatan Gempol tidak lagi sebagai pusat pelayanan lokal tetapi juga sebagai pusat pelayanan regional lintas batas. Pergeseran fungsi tersebut merupakan potensi yang dapat mendukung perkembangan Pasar Daerah Gempol, sehingga langkah yang perlu dilakukan adalah peningkatan fungsi pasar. Namun demikian, tetap diperlukan adanya pembatasan atas peningkatan fungsi yang akan dilakukan karena beberapa alasan, seperti:

Kecamatan Gempol bukan merupakan pusat SSWP dan hanya merupakan bagian dari SSWP yang berpusat di Kecamatan Bangil sehingga fungsi yang akan dibebankan kepada Kecamatan Gempol tidak lebih tinggi daripada Kecamatan Bangil.

Kondisi dan perkembangan wilayah Kecamatan Gempol akan sangat dipengaruhi kondisi wilayah bencana lumpur sidoarjo karena jarak antara kedua wilayah tersebut dekat.

Sebagian pelaku industri kecil dan menengah masih enggan memanfaatkan sarana perdagangan yang ada di Pasar Daerah Gempol untuk memasarkan hasil produksinya karena dianggap Pasar Daerah Gempol belum cukup terkenal dan bersaing di pasar yang luas.

Implementasi dari peningkatan fungsi pasar yang akan diterapkan pada Pasar Daerah Gempol adalah peningkatan kelas pasar. Dalam pelaksanaannya, kelas Pasar Daerah Gempol ditingkatkan dari pasar kelas II menjadi kelas I. Peningkatan kelas pasar ini harus diimbangi dengan pengembangan unsur-unsur pendukung pasar, yang meliputi: pengembangan ruang pasar, fasilitas pendukung pasar, sistem transportasi, komoditas perdagangan, dan manajemen pengelolaan pasar. Peningkatan kualitas pelayanan unsur-unsur pendukung pasar tersebut, pada akhirnya diharapkan mampu memenuhi tujuan pengembangan Pasar Daerah Gempol sebagai pendukung pusat perdagangan regional.

\section{E. KESIMPULAN DAN REKOMENDASI}

Berdasarkan pada hasil analisis, maka dalam penelitian ini terdapat beberapa kesimpulan dan saran yang dapat dijadikan pertimbangan dalam penentuan konsep pengembangan Pasar Daerah Gempol pada masa mendatang. Adapun beberapa kesimpulan dan saran yang dimaksud masingmasing dapat dikemukakan sebagai berikut:

\section{Kesimpulan}

1. Berdasar pada pada hasil kajian ekonomi wilayah dan kebijakan pembangunan Kabupaten Pasuruan, aktivitas ekonomi Kabupaten Pasuruan tidak hanya bertumpu pada aktivitas sektor primer (pertanian, perkebunan, perikanan, dan pertambangan) tetapi juga pada aktivitas sektor sekunder (pelayanan jasa dan industri pengolahan). Pada wilayah kajian, sektor ekonomi unggulan yang berperan dalam mendukung perkembangan masyarakat adalah sektor sekunder berupa industri pengolahan.

2. Kecamatan Gempol bersama Kecamatan Bangil, Kecamatan Beji dan Kecamatan Pandaan memiliki industri mikro, kecil dan menengah yang cukup potensial. Aktivitas tersebut diperkirakan mampu menghasilkan produk-produk yang mampu menjadi produk unggulan Kabupaten Pasuruan, seperti kain bordir, konveksi, dan kerajinan perak. Penguatan sektor industri pengolahan ini diharapkan menjadi kunci pengembangan ekonomi masyarakat di wilayah kajian maupun di Kabupaten Pasuruan.

3. Pengembangan Pasar Daerah Gempol diharapkan mampu menangkap potensi ekonomi masyarakat berupa aktivitas industri kecil dan menengah tersebut, mengingat sampai saat 


\section{Journal of Indonesian Applied Economics}

Vol. 3 No. 2 Oktober 2009, 178-199

ini belum adanya upaya untuk mendukung perkembangan sektor industri kecil dan menengah tersebut secara terpadu.

4. Perkembangan Kecamatan Gempol selama ini tidak hanya dipengaruhi oleh perkembangan yang terjadi di wilayah Kabupaten Pasuruan akan tetapi juga perkembangan yang terjadi di wilayah sekitarnya seperti Kabupaten Mojokerto dan Kabupaten Sidoarjo. Sehingga kedepannya, pengembangan yang dilakukan di Kecamatan Gempol juga harus mempertimbangkan arah kebijakan yang diterapkan pada Kabupaten Mojokerto dan Kabupaten Sidoarjo.

5. Posisi strategis Kecamatan Gempol yang memungkinkan Pasar Daerah Gempol dapat melayani wilayah sekitar yang memiliki potensi ekonomi yang cukup besar dan sangat berpeluang untuk dapat dikembangkan, seperti Kecamatan Beji, Kecamatan Bangil, Kecamatan Pandaan serta wilayah perbatasan seperti Kecamatan Ngoro, dan Kecamatan Porong, maka Pengembangan Pasar Daerah Gempol tetap dimungkinkan untuk dilaksanakan. Hal ini dapat dilakukan mengingat Pasar Daerah Gempol diharapkan dapat berfungsi sebagai sarana untuk pengembangan ekonomi masyarakat, berarti memberikan multilpier efect.

6. Pengembangan Pasar Daerah Gempol juga akan berpotensi untuk meningkatkan pendapatan retribusi. Peningkatan jumlah obyek retribusi dan pengelolaan beberapa retribusi baru merupakan faktor-faktor yang cukup dominan dalam meningkatkan potensi retribusi Pasar Daerah Gempol dalam waktu mendatang.

\section{Rekomendasi}

Saran yang perlu dipertimbangkan dalam kegiatan pengembangan Pasar Daerah Gempol adalah:

1. Pengembangan Pasar Daerah Gempol diharapkan mampu menyesuaikan dengan fungsi yang diemban Kecamatan Gempol sebagai bagian dari SSWP I. Kecamatan Gempol hanya berfungsi sebagai pusat sekunder atau pendukung pusat pengembangan wilayah yang berpusat di Kecamatan Bangil. Apabila dalam beberapa kurun waktu kedepan wilayah Kecamatan Gempol mengalami perkembangan akibat pengembangan Pasar Daerah Gempol maka perlu dikaji kembali rencana tata ruang yang berlaku.

2. Perlu adanya studi lanjut mengenai relokasi pasar hewan dan pasar burung apabila dilaksanakan kegiatan pengembangan pasar Daerah Gempol.

\section{DAFTAR PUSTAKA}

Arikunto, Suharsimi, 1998, Prosedur Penelitian, Suatu Pendekatan Praktek, Rineka Cipta, Yogyakarta

Budiharsono, 2005, Teknik Analisis Pembangunan Wilayah Pesisir dan Laut, Pradnya Paramita, Jakarta.

Isard,Walter.1976, Methods of Regional Analysis : an Introduction to Regional Science. MIT Press. Massachusetts

Kottler, Philip \& A.B.Susanto 1999, Manajemen Pemasaran di Indonesia, Analisis,Perencanaan,Implementasi dan Pengendalian, Salemba Empat, Jakar

Muljaningsih, Sri, 1989, Studi Pengembangan Wilayah Kabupaten Gresik melalui Identifikasi Kesempatan Kerja di Sektor Pertanian dan Sektor Industri, ITB, Bandung

Riyadi dan Brata Kusumah, Deddy Supriady,2003, Perencanaan Pembangunan Daerah, Gramedia Pustakatama,Jakarta

Rencana Tata Ruang Wilayah Kabupaten Pasuruan, 2008 
Schumer, 1974, Elements of Transport, Butterworths, Sydney

Yoeti, Oka.A, 1996, Pengantar Ilmu Pariwisata, Angkasa, Bandung

Warpani,Suwardjoko,1977, Analisis Kota dan Daerah, Penerbit ITB, Bandung

Warpani, 2002, Pengelolaan Lalu Lintas dan Angkutan Jalan, Penerbit ITB, Bandung 